\title{
Holocene distribution of woody taxa at the westernmost limit of the Circumboreal/Mediterranean boundary: Evidence from wood remains
}

\author{
Juan M. Rubiales ${ }^{\mathrm{a}, *}$, Javier Ezquerra ${ }^{\mathrm{b}}$, Castor Muñoz Sobrino ${ }^{c}$, María M. Génova ${ }^{\mathrm{a}}$, Luis Gil ${ }^{\mathrm{a}}$, \\ Pablo Ramil-Rego ${ }^{d}$, Fernando Gómez Manzaneque ${ }^{\text {a }}$ \\ a Escuela de Ingeniería Forestal y del Medio Natural, Universidad Politécnica de Madrid, 28040 Madrid, Spain

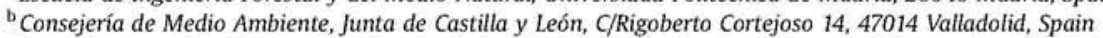 \\ ${ }^{\mathrm{C}}$ Departamento Bioloxía Vexetal e Ciencias do Solo, Universidade de Vigo, As Lagoas, Marcosende s/n, 36310 Vigo, Spain

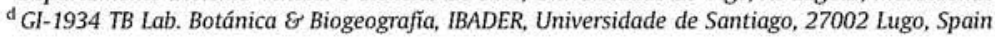

\section{A R T I C L E I N F O}

\section{Article history:}

Received 9 April 2011

Received in revised form

11 November 2011

Accepted 12 November 2011

Available online 17 January 2012

\section{Keywords:}

Palaeoecology

Historical biogeography

Holocene

Megafossil

Iberian Peninsula

\begin{abstract}
A B S T R A C T
Macrofossils and megafossils of different genera, which were found in twelve localities in the mountains of northwest Iberia, provide spatially precise evidence of their distribution in the region during the Holocene. Macrofossils were recovered from mires, eroded peat bogs and lakes, identified by their wood anatomy and dated using radiocarbon methods. Conifers (Pinus), deciduous trees (Betula, Salix, Quercus) and shrubs (Erica, Fabaceae) were identified. The findings of Pinus gr. sylvestris/nigra have special biogeographical significance. The available palaeoecological data from the Cantabrian Range and nearby mountains (Ancares and Courel) indicate that pines have grown during the Holocene over the highlands of the western part of the Cantabrian Range area as a natural vegetation element. Nevertheless, Pinus sylvestris is the only pine species that is currently present in the Cantabrian Mountains, and its natural distribution area is now limited to a few enclaves. In this study, we provide a number of conclusive findings demonstrating that the past distribution of Pinus gr. sylvestris/nigra in this region suffered an important range contraction during the last two millennia. Historical data also support this idea, as they strongly suggest that this species survived well into the historical period.
\end{abstract}

(c) 2011 Elsevier Ltd. All rights reserved.

\section{Introduction}

The southwestern edge of the Circumboreal biogeographical region is found in the mountains of northwestern Iberia (Takhtajan, 1986) and constitutes the southern range edge of a number of animal and plant species that are widely distributed at higher latitudes. Despite the fact that this area bears a high degree of floristic endemicity (Costa et al., 1992; Izco et al., 2004; Llamas et al., 2007) and enrichment of narrowly endemic invertebrates (Vinçon and Pardo, 2004) and vertebrates (IUCN, 2010), major conservation efforts in this area have traditionally targeted longterm isolated, genetically differentiated populations that currently live in relatively confined areas (Gómez and Lunt, 2007). These characteristics apply to the Cantabrian capercaillie (Tetrao urogallus) and the Cantabrian brown bear (Ursus arctos) (Storch, 2007; Valdiosera et al., 2008), which are two important foci of Spanish conservation policies.

\footnotetext{
* Corresponding author. Tel.: +3491336 637 8; fax: +3491 5439557. E-mail address: jm.rubiales@upm.es (J.M. Rubiales).
}

However, biogeographical interest in regional tree vegetation has remained limited even if some tree species probably could have played key roles in the Holocene history of certain relictual animal populations (Rubiales et al., 2009). Long-term temporal records have become valuable sources of data that provide a larger perspective on the species distribution, dynamics and conservation of ecosystems (Birks, 1996; Carrión, 2002; Gillson and Willis, 2004). Recent advances in palaeoecological research indicate the existence of both glacial and interglacial refugia in northwestern Iberia, especially in the coastal areas (Gómez-Orellana et al., 2007). Furthermore, the available data for the innermost mountains have served to highlight the changing biogeographical importance of some key species in the area, as is the case for Fagus sylvatica L. (Muñoz Sobrino et al., 2009) and Pinus sylvestris L. (Rubiales et al., 2008).

In this area of southwestern Europe, most of the available information comes from the study of pollen sequences, and few studies have been conducted on macrofossil or megafossil remains (Alcalde et al., 2006; Carrión et al., 2010a). The pollen-derived reconstructions that have been recently developed in the Cantabrian Mountains offer a large body of sequential data (e.g. Ramil- 
Rego et al., 1998; Muñoz Sobrino et al., 2001, 2005; López Merino, 2009; Jalut et al., 2010), but, due to the taphonomic and taxonomic limitations of pollen analysis, the combination of macrofossil and microfossil data is necessary to avoid potentially inaccurate inferences on a species range's evolution and dynamics (Birks, 2003; Froyd, 2005). Furthermore, an additional source of data regarding past tree distribution has been obtained from the archaeobotanical record (Figueiral and Carcaillet, 2005), but the interpretation of this type of information is limited by cultural habits and is restricted to human-selected locations, which are frequently chosen because of their productivity or strategic position (Théry-Parisot et al., 2010). Thus, non-archaeological sites become enclaves of paramount interest to provide evidence of past range distributions and altitudinal limits of species. Some recent studies exemplify how certain features of the vegetation history could only have been detected by macrofossil analysis of nonarchaeological sites (e.g. Birks and Birks, 2000; Carcaillet and Muller, 2005; Kullman, 2008).

This study compiles unpublished data of tree megafossils and macrofossils that were recovered during ten years of prospecting in diverse environments of the Cantabrian Mountain Range and adjacent mountains (Table 1). In combination with palynological, archaeological and historical information, these data help us to understand the evolution and environmental history of vegetation in the western Cantabrian range during the Holocene. The mechanisms that exert control over vegetation changes or stability over time are also discussed in light of this new information.

\section{Study area}

\subsection{Regional setting}

This study examined sites that are spread along the western part of the Cantabrian Range, the most important mountain chain of northwestern Iberia, which straddles the boundary between the Circumboreal and Mediterranean biogeographical regions. The range extends over ca. $350 \mathrm{~km}$ in a prevailing east-west direction, running nearly parallel to the sea and becoming more complex to the west. The Ancares and Courel Mountains are extensions of the main range toward the southwest. For convenience, they will be referred to as part of the Cantabrian Range
(Fig. 1). Peña Ubiña (2417 $\mathrm{m}$ asl) is the highest mountain in the western half of the Cantabrian range, with a few other summits peaking over $2000 \mathrm{~m}$.

Climatic differences between northern and southern slopes here have had a great impact on the local paleoecology (Ramil-Rego et al., 1998). The summit determines a sharp divide in the amount and distribution of precipitation, mostly due to a rain shadow effect. These differences cause dramatic contrasts between north and south slopes and can reach more than $1000 \mathrm{~mm} / \mathrm{year}$ locally (near to the Bierzo depression (Fig. 2)). The variability in precipitation also corresponds to strong variations in the duration of the frost season and in the water availability during the summer. Generally, there is little or no water stress in the northern slopes while summer drought is generally severe in the southern slopes. Furthermore, the differences of insolation between the two slopes intensify this dissimilarity. A second gradient of oceanicity is shown in the west-east direction because westerly oceanic winds affect the western mountains (Ancares and Courel Mountains) more strongly than the eastern and central section of the Cantabrian Range.

Climate, topography and geology make this area ecologically diverse. Palaeozoic siliceous bedrock predominates (slate, sandstone, schist and quartzite), although limestone is also present (and even dominates locally), and distinct physiography from undulating hilly lands to deep valleys and sharp relief are widely found. Glacial landforms are abundant, due to the influence of oceanic winds that have resulted in greater snowfall rates during colder stages of the Pleistocene (Gutierrez Elorza, 1994).

At the regional scale, modern vegetation clearly responds to the climatic gradient of oceanicity-continentality. Today, a mild and humid climate favours the development of deciduous forests, which are dominated by Quercus robur L., Quercus petraea (Mattuschka) Liebl and their hybrid ( $Q . x$ rosacea Bechst), F. sylvatica $L$. (which are scarce in the western part of the region) and Betula pubescens Ehrh on the upper slopes. In the deepest soils, diverse mixed forests grow (including Fraxinus excelsior L., Corylus avellana L., Acer pseudoplatanus L. and others). By contrast, in the inner and southern slopes, other types of woodlands are found, mostly dominated by Quercus pyrenaica Willd., patches of Quercus faginea Lam., Juniperus thurifera L. and, on both slopes, shrub communities including Ericaceae and Fabaceae within a well-developed Poaceae

Table 1

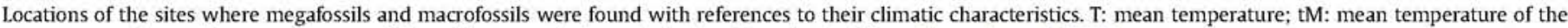
warmest month; tm: Mean temperature of the coldest month; P: precipitation. Data obtained from Ninyerola et al. (2005).

\begin{tabular}{|c|c|c|c|c|c|c|c|c|c|}
\hline Site & Geographic location & $\begin{array}{l}\text { Municipality } \\
\text { (province) }\end{array}$ & Latitude-Longitude & Altitude (m) & $\begin{array}{l}\mathrm{T} \\
\left({ }^{\circ} \mathrm{C}\right)\end{array}$ & $\begin{array}{l}\mathrm{tM} \\
\left({ }^{\circ} \mathrm{C}\right)\end{array}$ & $\begin{array}{l}\operatorname{tm} \\
\left({ }^{\circ} \mathrm{C}\right)\end{array}$ & $\begin{array}{l}P \\
\left(\mathrm{~mm} . \text { year }^{-1}\right)\end{array}$ & Deposit type \\
\hline Lagoa de Lucenza & Courel & $\begin{array}{l}\text { Folgoso do Courel, } \\
\text { (Lugo) }\end{array}$ & $42.58-7.10$ & 1375 & 7.8 & 21.8 & -2.5 & 1720 & Small lake \\
\hline A Golada & Ancares & $\begin{array}{l}\text { Pedrafita do Cebreiro } \\
\text { (Lugo) }\end{array}$ & $42.72-7.01$ & 1210 & 8.5 & 22.4 & -2.1 & 1550 & Peat bog \\
\hline Brañas de Lamela & Ancares & Tejeira (León) & $42.77-6.85$ & 1285 & 8.1 & 21.8 & -2.5 & 1600 & Peat bog \\
\hline Suárbol & Ancares & Suárbol (Léon) & $42.86-6.84$ & 1370 & 7.6 & 20.3 & -3.0 & 1680 & Peat bog \\
\hline Balouta & Ancares & Balouta (León) & $42.88-6.79$ & 1300 & 7.5 & 20.5 & -2.9 & 1700 & Soil profile \\
\hline Sosas & $\begin{array}{l}\text { Laciana, W Cantabrian } \\
\text { Range }\end{array}$ & $\begin{array}{l}\text { Sosas de Laciana } \\
\text { (León) }\end{array}$ & $42.95-6.29$ & 1480 & 7.0 & 22.3 & -2.5 & 1210 & Peat bog \\
\hline Mena & $\begin{array}{l}\text { Babia, W Cantabrian } \\
\text { Range }\end{array}$ & $\begin{array}{l}\text { Mena de Babia } \\
\text { (León) }\end{array}$ & $42.92-6.12$ & 1650 & 8.0 & 22.0 & -2.3 & 1190 & Stream bank \\
\hline Riolago & $\begin{array}{l}\text { Babia, W Cantabrian } \\
\text { Range }\end{array}$ & $\begin{array}{l}\text { Riolago de Babia } \\
\text { (León) }\end{array}$ & $42.93-6.08$ & 1750 & 7.0 & 24.1 & -3.6 & 1200 & Lake/Glacial deposit \\
\hline Torrestío & $\begin{array}{l}\text { Babia, W Cantabrian } \\
\text { Range }\end{array}$ & Torrestío (León) & $43.02-6.02$ & 1520 & 7.0 & 22.5 & -4.1 & 1040 & Peat bog \\
\hline Aralla & $\begin{array}{l}\text { Luna, W Cantabrian } \\
\text { Range }\end{array}$ & Aralla de Luna (León) & $42.90-5.83$ & 1530 & 8.0 & 24.1 & -4.1 & 1150 & Stream bank \\
\hline Riopinos & $\begin{array}{l}\text { Central Cantabrian } \\
\text { Range }\end{array}$ & $\begin{array}{l}\text { Valdelugueros } \\
\text { (León) }\end{array}$ & $43.04-6.05$ & 1430 & 4.0 & 21.4 & -7.5 & 1300 & $\begin{array}{l}\text { Peat bog and } \\
\text { fens/stream bank }\end{array}$ \\
\hline $\begin{array}{r}\text { San Feliz de la } \\
\text { Lavanderas }\end{array}$ & $\begin{array}{l}\text { La Cepeda, Cantabrian } \\
\text { Foothills }\end{array}$ & $\begin{array}{l}\text { San Feliz de la } \\
\text { Lavanderas (León) }\end{array}$ & $42.68-5.97$ & 1300 & 9.0 & 26.0 & -2.4 & 740 & Peat bog \\
\hline
\end{tabular}




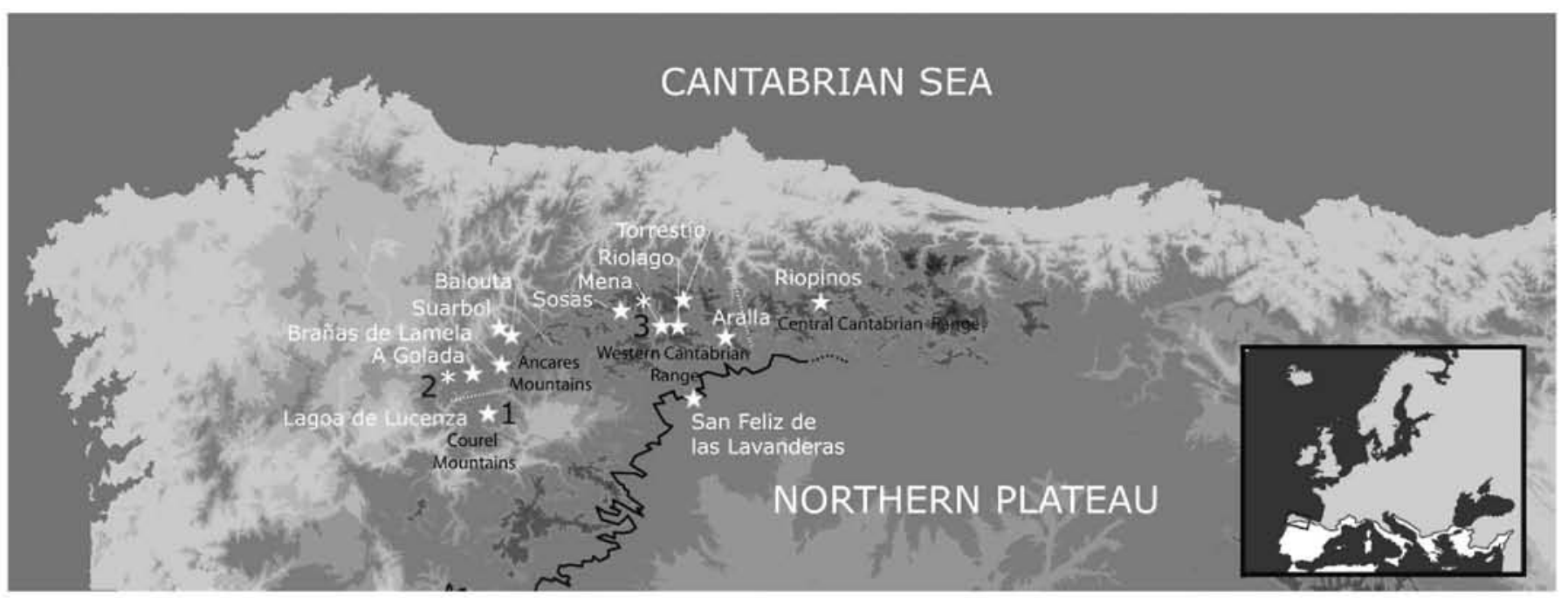

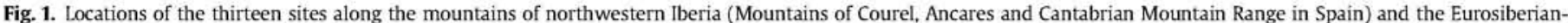

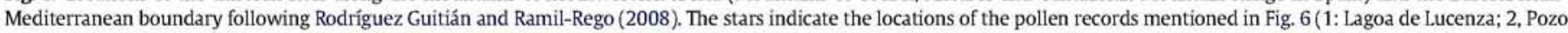
do Carballal; 3, La Mata).

herbaceous layer near the summits. Pine forests, which are well developed in all other mountain ranges of northern lberia, are nearly absent from the natural vegetation of the Cantabrian Mountains. Small, natural-looking stands of $P$. sylvestris only exist in the headwaters of the Porma and Carrión Rivers, of which the Lillo populations have the largest and best specimens.

Anthropogenic impacts are particularly important for understanding the current landscape configuration. The use of fire has served as a tool to prevent succession toward forested stages and has been used extensively in cattle management practices and, more locally, subsistence agriculture practices. Shrublands and herbaceous pasturelands have been widely favoured by human activities at mid-altitudes and on plains, being part of initial stages of vegetation succession (Ramil-Rego et al., 1998), but they are also stable communities in wetlands, rocky soils and at mountain ridges.
Shrub communities are frequently found on steep slopes, and, at lower elevations, fertile pastures are maintained instead of mixed forests. In agroforestry systems, namely, soutos and dehesas, humans have widely changed the forest structure, creating patchy forests in which intense tree clearings and pruning leave open spaces that are used as a source of cattle fodder. Finally, recent afforestation activities with both softwoods and hardwoods (e.g., Pinus spp., Castanea) have heavily influenced the current habitat structure in part of the study area.

\subsection{Description of the sites}

The Lagoa de Lucenza site ( $1375 \mathrm{~m}$ asl) is a small, temporal lake (normally dry during the summer) that is situated in a basin of glacial origin and is enclosed by an ancient moraine. Its

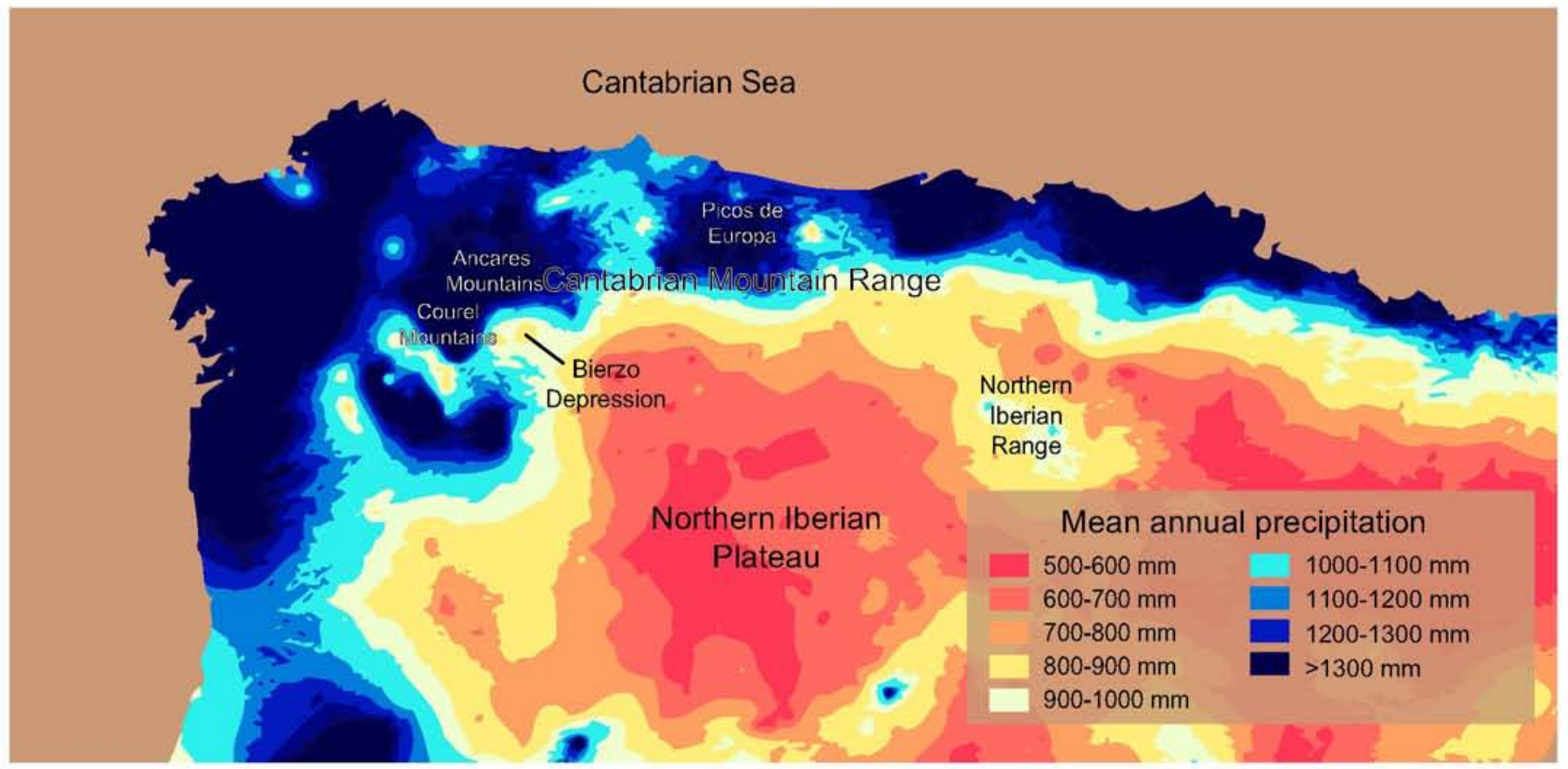

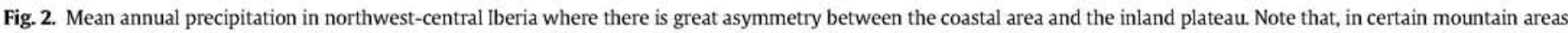
close to our study area, dramatic differences occur in terms of mean precipitation between the northern and southern slopes. Image modified from Ninyerola et al. (2005). 
sedimentology consists of gyttja and clay with varying values of organic matter and gravels (Muñoz Sobrino et al., 2001). The woody remains analysed in this study were located $50-70 \mathrm{~cm}$ deep in the layer of gyttja.

A Golada ( $1210 \mathrm{~m}$ asl) is a peat bog that originated from the rupture of a phreatic level. Here, several sedimentary facies were identified. The upper facies is fibrous peat (up to $95 \mathrm{~cm}$ deep) and is followed by a level of humified peat (95-150 cm deep), clays $(150-200 \mathrm{~cm})$ and saprolites $(200-265 \mathrm{~cm})$. Wood remains were recovered at ca. $40,80,110$ and $210 \mathrm{~cm}$ deep.

Suárbol ( $1370 \mathrm{~m}$ asl) is a peat bog situated at the bottom of an ancient glacial valley. The upper layer of the core that was made at Suárbol is composed of fibrous peat (up to $65 \mathrm{~cm}$ deep) followed by a shallow layer of sand and gravel and another level of humified peat $(85-125 \mathrm{~cm})$. Wood remains were located at depths of ca. 55 and $110 \mathrm{~cm}$.

Brañas de Lamela ( $1285 \mathrm{~m}$ asl) is another peat bog that is situated at the right margin of a stream named Valongo in a zone of impeded drainage by an ancient moraine. The upper sediments are fibrous peat (up to $110 \mathrm{~cm}$ deep) and humified peat $(110-180 \mathrm{~cm})$. Woody remains were recovered at depths of $100-120 \mathrm{~cm}$. Further details on the local settings of the aforementioned sites can be found in Muñoz Sobrino et al. (1997).

The remains from Balouta ( $1300 \mathrm{~m}$ asl) were recovered in a polycyclic soil where a trench revealed signs of former periglacial activity (Moares et al., 1996). The upper horizon $(0-40 \mathrm{~cm})$ is composed of clay with abundant organic matter and a basal layer of slates. It is followed by another clayey-silt horizon $(40-50 \mathrm{~cm})$ in which charcoal was recovered with another layer of slate at the bottom of this horizon. At the deepest part of this soil, there is another clayey-silt horizon that is more abundant in gravel $(55-80 \mathrm{~cm})$. The landscape of the valley of Balouta is almost treeless today, containing dense shrubs of Erica spp., Cytisus and Genista.

The woody remains from Sosas (Sosas de Laciana, $1480 \mathrm{~m}$ asl) were located in a pit that was created in a peat bog when reforestation work was being done close to the site. It was recovered at a depth of ca. $40 \mathrm{~cm}$ in a treeless environment that included Erica tetralix, Genista anglica and Sphagnum. The surrounding lithology is slate, and the vegetation is mainly composed of heathlands (Erica australis) and some young and isolated Betula individuals.

The site of Mena (Mena de Babia, $1650 \mathrm{~m}$ asl) is located in an area of acidic soils that was developed on quartzites. Megafossils were recovered embedded in the soil in an eroded stream bank at ca. $15 \mathrm{~cm}$ in depth. Local vegetation is mainly composed of heathlands with $E$. australis and broom (mainly Genista florida and Cytisus oromediterraneus) and scattered individuals of Betula alba and $Q$. petraea.

In Riolago (Riolago de Babia, $1750 \mathrm{~m}$ asl) megafossils were preserved in the sediments of a moraine that was closing an ancient glaciar cirque, which is now a small lake. The lithology is composed of slates and quartzites, and the regional vegetation is composed of heathlands of $E$. australis and broom (mainly Genista obtusirramea) and scattered individuals of Betula and $P$. sylvestris.

The woody remains of Torrestío ( $1520 \mathrm{~m}$ asl) were located on a fen when construction was being done to develop groundwater uptake in the area. Megafossils were recovered at 30-40-cm deep, embedded in peat. The vegetation present at the top of the fen is primarily heaths (E. tetralix) and Sphagnum. The vegetation nearby is mainly composed of heathlands (E. australis) and broom ( $G$. florida and C. oromediterraneus) with isolated individuals of $B$. alba.

The findings of Riopinos (Valdelugueros, León) were recovered on a peat bog and at the bank of a stream at ca. $30 \mathrm{~cm}$ in depth. They were located during work on the construction of a road. The vegetation in the site is dominated by E. tetralix and Sphagnum spp. (on the peat bog) and heathlands of E. australis and Calluna vulgaris, including Vaccinium myrtillus and scattered individuals of $B$. alba and $Q$, robur.

In Aralla (Aralla de Luna, $1530 \mathrm{~m}$ asl), during the process of digging for the construction of a road, woody remains were located near the surface at ca.10-20 cm in depth. They were embedded in peaty sediments at the margin of a stream. The lithology in the area is a mixture of slates, limestones and quartzites. The vegetation in the area is composed of shrublands, including Genista hispanica, $G$. florida and Cytisus oromediterraneus.

Finally, the site of San Feliz de las Lavanderas ( $1275 \mathrm{~m}$ asl) is located at a lower altitude on a fen through which a shallow stream currently flows. The predominant lithology is quartzite. Remains were located embedded in the sediment at ca.10-20 cm deep. The findings were made during the process of digging for the construction of a track. Present-day vegetation includes $E$. tetralix and $C$. vulgaris (locally abundant at the site) and heathlands with Erica australis, Erica umbellata and Pterospartum tridentatum.

\section{Materials and methods}

Altogether, 89 wood remains from 12 sites were analysed through diverse histological methods to obtain a more precise taxonomical diagnosis based on wood anatomy (Figs. 3 and 4). First, all non-charred samples were prepared in thin section with a sliding microtome (radial, tangential and cross sections), stained with safranin and embedded on a hardening epoxy, as described by Schweingruber (2007). However, when biological decay affected the woody remains, methodological limitations hindered the obtaining of high-quality slides. In these cases, additional analyses were carried out. As charcoal, decaying wood was studied by dark-field reflection microscopy after manually preparing the different sections of the specimens. This methodology allows the observation of some useful features for identification, but a number of important diagnostic elements cannot be shown. In this case, slivers of wood were macerated in Schultz's solution $\left(800 \mathrm{~cm}^{3}\right.$ of $\mathrm{HNO}_{3}, 4 \mathrm{~g} \mathrm{~K}_{3} \mathrm{ClO}_{4}, 200 \mathrm{~cm}^{3} \mathrm{H}_{2} \mathrm{O}$ ), mounted with water or glycerine jelly and observed using traditional transmission microscopy.

Identifications were made by comparing specimens with reference collections of modern wood and using classic atlases of wood anatomy identification (Greguss, 1955; Jacquiot, 1955; Peraza, 1964; García and Guindeo, 1988; Schweingruber, 1990; Vernet et al., 2001). As not all species were examined in previous studies, complementary efforts in wood identification were made by collecting new samples of modern wood, preparing them with the same methodology and comparing the fossil remains with this new material.

Conventional radiocarbon dating was carried out in the Centrum vor Isotopen Onderzoek, Groningen University (Groningen, The Netherlands), the Rocasolano Institute of Physical Chemistry, National Scientific Research Council (Madrid, Spain), Beta Analytic Inc. (Florida, USA) and Chrono Centre (Belfast, UK). Some of the dates reported in this study were previously published in Muñoz Sobrino et al. (1997, 2001). The calibration of all dated samples was performed using CALIB REV 6.0.0 software (Stuiver and Reimer, 1993) and the newest calibration dataset (Reimer et al., 2009).

\section{Results}

Eighty-nine wood specimens were identified, which belong to six different taxa. The wood samples collected from the westernmost sites were mostly derived from medium-to-small-sized branches, and the anatomical and morphological features rarely enhanced the identification attained by microfossil analysis. All of 


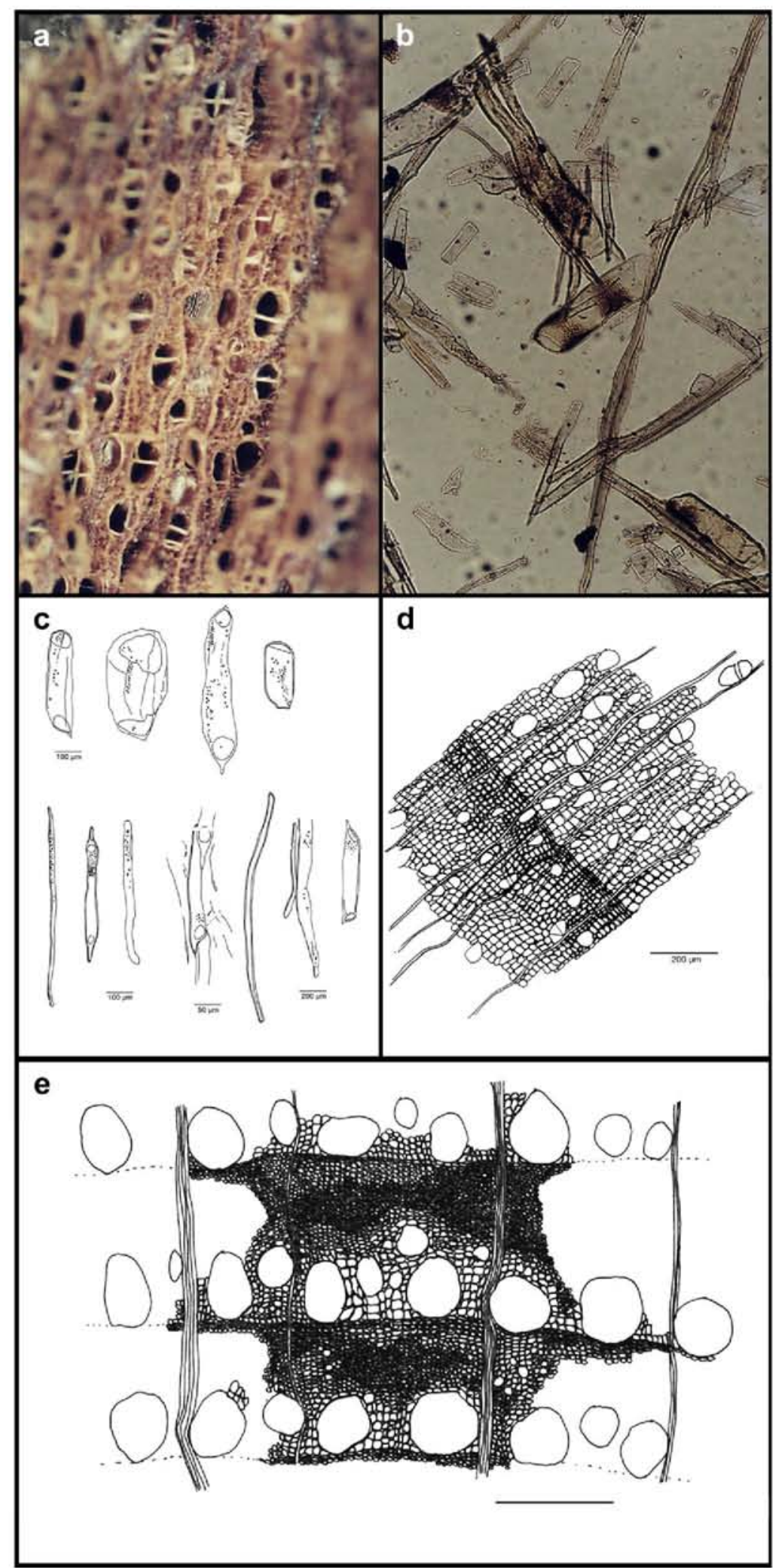

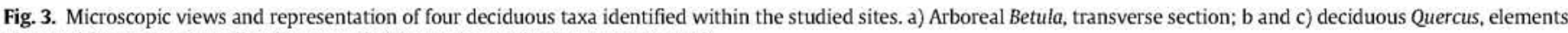
observed by maceration; d) Salix sp.; and e) Leguminosae (Cytisus scoparius tp.).

these samples were identified as hardwoods, as presented in Table 2. By contrast, megafossil identifications from the central sections of the Cantabrian Range corresponded mainly to conifers, and no hardwoods samples were identified.
Radiocarbon dating showed that the ages of the collected material spanned the time period from ca. 9400 to 1100 cal yr BP (Table 3). However, most of the samples correspond to the mid-and late Holocene. Early Holocene remains dated $9150 \mathrm{cal}$ yr BP were 


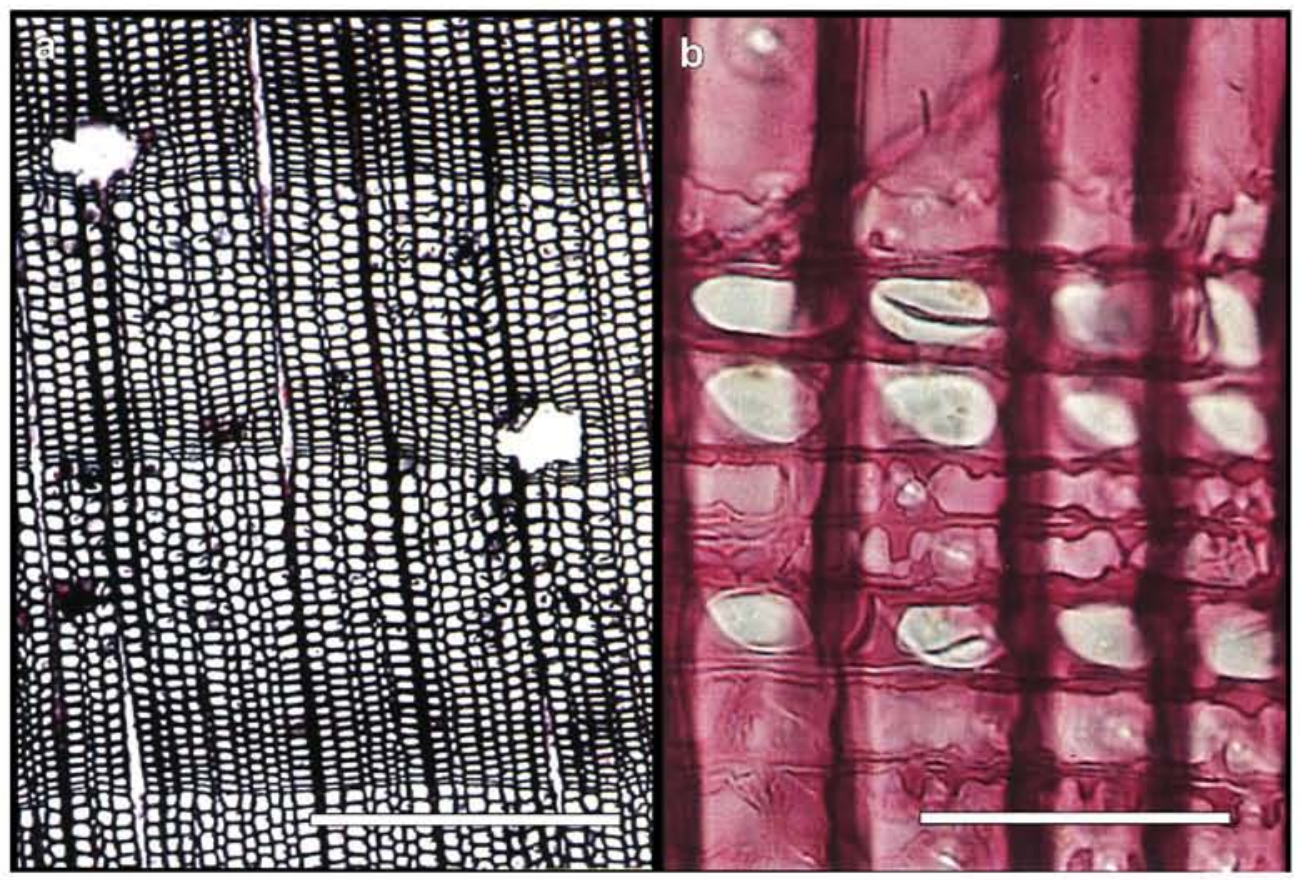

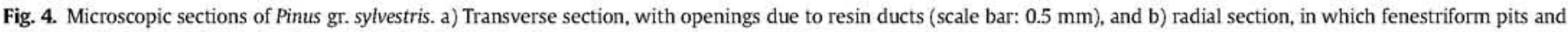
dentate radial tracheids can be observed (scale bar: $0.1 \mathrm{~mm}$ ).

only located at the Riolago site, where mid-Holocene remains were also found (dated $4338 \mathrm{cal} \mathrm{yr} \mathrm{BP).}$

\section{Discussion}

5.1. New macrofossil wood data in the mountains of northwestern Iberia: biogeographic considerations

The new findings extend the available palaeoecological dataset for macrofossils in the region by both filling in geographical gaps throughout the Cantabrian Range and by yielding new Holocene dates for different tree species of major interest. The Pinus gr. sylvestris findings are of special biogeographical significance because

Table 2

Wood and charcoal identification.

\begin{tabular}{|c|c|c|c|c|c|}
\hline Site & Logs & Twigs & $\begin{array}{l}\text { Pieces } \\
\text { of wood } \\
\text { or branches }\end{array}$ & $\begin{array}{l}\text { Charcoal } \\
\text { fragments }\end{array}$ & $\begin{array}{l}\text { Identified } \\
\text { taxa }\end{array}$ \\
\hline $\begin{array}{l}\text { Lagoa de } \\
\text { Lucenza }\end{array}$ & & 8 & 10 & & Salix atrocinerea tp. \\
\hline A Golada & 4 & $\begin{array}{l}1 \\
5 \\
4 \\
4\end{array}$ & & & $\begin{array}{l}\text { Betula pubescens tp. } \\
\text { Erica arborea tp. } \\
\text { Betula pubescens tp. } \\
\text { Quercus } \mathrm{sp} . \\
\text { (deciduous) }\end{array}$ \\
\hline Suárbol & & 2 & 1 & & Betula pubescens tp. \\
\hline $\begin{array}{r}\text { Brañas de } \\
\text { Lamela }\end{array}$ & & & 13 & & Betula pubescens tp. \\
\hline Balouta & & & & $\begin{array}{r}5 \\
15\end{array}$ & $\begin{array}{l}\text { Cytisus tp. } \\
\text { Quercus sp. } \\
\text { (deciduous) }\end{array}$ \\
\hline Sosas & 2 & & & & Pinus gr. sylvestris \\
\hline Mena & 1 & & & & Pinus gr. sylvestris \\
\hline Riolago & 3 & & & & Pinus gr. sylvestris \\
\hline Torrestio & 1 & & & & Pinus gr. sylvestris \\
\hline Aralla & 1 & & & & Pinus gr. sylvestris \\
\hline Riopinos & 8 & & & & Pinus gr. sylvestris \\
\hline $\begin{array}{c}\text { San Feliz de las } \\
\text { Lavanderas }\end{array}$ & 1 & & & & Pinus gr. sylvestris \\
\hline
\end{tabular}

pine is now extinct in the western section of the Cantabrian Range. The new data that we present here allow us to refine the current hypotheses on its Holocene range history, which until now, has been determined by a limited fossil dataset (Sánchez Hernando et al., 1999; Rubiales et al., 2008). In the present work, most of the evidence is directly dated and provided from nonarchaeological sites, and these data reinforce and increase the precision of the information obtained from other palynological and archaeological sources.

In general terms, the information provided by macrofossils in the present study shows great concordance with existing pollen records (Muñoz Sobrino et al., 1997, 2001). In the sites located on the westernmost section of the range (Lagoa de Lucenza, A Golada, Brañas de Lamela, Balouta and Suárbol, where macrofossils were recovered from the same cores when pollen sequences were obtained), the woody remains generally correspond to the dominant taxa occurring in that part of the record, thereby confirming their local existence in the area (Fig. 5).

In the other cases, the comparison of the woody macrofossil information with the ecologically nearest pollen deposits also shows strong consistency, although the woody macrofossil information is able to detect local presence when low pollen percentages occur. This phenomenon is notable for the case of Pinus, as pollen percentages below $15 \%$ during the Holocene are frequently interpreted as long-distance pollen transport, due to the large-scale production and dispersion of this pollen type (e.g. Andrade et al., 1994; García Antón et al., 2006). Woody macrofossil and pollen evidence, however, could also reflect the high environmental variability observed in the area, as represented by patched forests or alternation in the dominant species through the Cantabrian Range. Some palynological studies in other sites from the study area have interpreted moderate Pinus percentages as signals from the pinewood of Lillo (Watts, 1986; Puente García et al., 1998) rather than data supporting a larger distribution of Pinus in these mountains. The interpretation of the role of pines in these mountains might also have been biased by prejudices against pines, which are derived from their extensive use in reforestation 
Table 3

Radiocarbon dates from the sites where macrofossils were analysed. Dates with (*) were previously published (Muñoz Sobrino et al., 1997, 2001).

\begin{tabular}{|c|c|c|c|c|c|c|c|}
\hline Lab code & Site & Material & $\begin{array}{l}\text { Radiocarbon } \\
\text { method }\end{array}$ & $\begin{array}{l}\text { Wood species } \\
\text { detected in the site }\end{array}$ & $\begin{array}{l}\text { Radiocarbon } \\
\text { ages (yr BP) }\end{array}$ & $\begin{array}{l}\text { Two-sigma } \\
\text { calibrated ages } \\
\text { (cal yr BP) }\end{array}$ & $\begin{array}{l}\text { Med probability } \\
\text { (cal yr BP) }\end{array}$ \\
\hline CSIC-1116* & Suárbol & Bulk sediment & $\begin{array}{l}\text { Standard } \\
\text { radiometric }\end{array}$ & Betula pubescens tp. & $1250 \pm 25$ & $1086-1272$ & 1211 \\
\hline Beta-263692 & Mena & Wood & $\begin{array}{l}\text { Standard } \\
\text { radiometric }\end{array}$ & Pinus gr. sylvestris & $1490 \pm 60$ & $1299-1518$ & 1384 \\
\hline UBA-17596 & Aralla & Wood & AMS & Pinus gr. sylvestris & $1659 \pm 26$ & $1445-1689$ & 1559 \\
\hline Beta-169212 & Riopinos & Wood & $\begin{array}{l}\text { Standard } \\
\text { radiometric }\end{array}$ & Pinus gr. sylvestris & $2040 \pm 60$ & $1871-2150$ & 2005 \\
\hline CSIC-1115* & Brañas de Lamela & Bulk sediment & $\begin{array}{l}\text { Standard } \\
\text { radiometric }\end{array}$ & Betula pubescens tp. & $3090 \pm 35$ & $3218-3381$ & 3313 \\
\hline GrN-21453* & A Golada & Wood & $\begin{array}{l}\text { Standard } \\
\text { radiometric }\end{array}$ & $\begin{array}{l}\text { Betula pubescens tp. } \\
\text { Salix atrocinerea tp. }\end{array}$ & $3390 \pm 40$ & $3485-3816$ & 3636 \\
\hline GrN-22829* & Lagoa de Lucenza & Bulk sediment & $\begin{array}{l}\text { Standard } \\
\text { radiometric }\end{array}$ & $\begin{array}{l}\text { Salix atrocinerea tp., } \\
\text { Betula pubescens tp. } \\
\text { Quercus sp. deciduous }\end{array}$ & $3710 \pm 50$ & $3903-4227$ & 4050 \\
\hline Beta-169211 & Riolago & Wood & $\begin{array}{l}\text { Standard } \\
\text { radiometric }\end{array}$ & Pinus gr. sylvestris & $3910 \pm 60$ & $4155-4517$ & 4338 \\
\hline Beta-169214 & Torrestío & Wood & $\begin{array}{l}\text { Standard } \\
\text { radiometric }\end{array}$ & Pinus gr. sylvestris & $4080 \pm 70$ & $4424-4821$ & 4602 \\
\hline GrN-20823 & Balouta & Charred remains & $\begin{array}{l}\text { Standard } \\
\text { radiometric }\end{array}$ & $\begin{array}{l}\text { Quercus sp. deciduous } \\
\text { Cytisus tp. }\end{array}$ & $4280 \pm 40$ & $4711-4965$ & 4850 \\
\hline Beta-179064 & Sosas & Wood & $\begin{array}{l}\text { Standard } \\
\text { radiometric }\end{array}$ & Pinus gr. sylvestris & $4490 \pm 60$ & $4891-5313$ & 5145 \\
\hline Beta-169213 & Riopinos & Wood & $\begin{array}{l}\text { Standard } \\
\text { radiometric }\end{array}$ & Pinus gr. sylvestris & $5180 \pm 70$ & $5747-6178$ & 5943 \\
\hline Beta-179063 & Sosas & Wood & $\begin{array}{l}\text { Standard } \\
\text { radiometric }\end{array}$ & Pinus gr, sylvestris & $5530 \pm 70$ & $6192-6463$ & 6334 \\
\hline UBA-17595 & $\begin{array}{l}\text { San Feliz de las } \\
\text { Lavanderas }\end{array}$ & Wood & AMS & Pimus gr. sylvestris & $5742 \pm 31$ & $6453-6636$ & 6539 \\
\hline Beta-169210 & Riolago & Wood & $\begin{array}{l}\text { Standard } \\
\text { radiometric }\end{array}$ & Pinus gr. sylvestris & $8190 \pm 60$ & $9007-9396$ & 9151 \\
\hline
\end{tabular}

programmes during the 20th century throughout Spain (ValbuenaCarabaña et al., 2010). Other studies have suggested that pinewoods existed in these mountains during most of the Holocene (Muñoz Sobrino et al., 2007). The data presented in this study support the indigenous character of Pinus gr. sylvestris in the entire area and a wider distribution of pinewoods in the past and provide us the opportunity to reinterpret old sequences with a new perspective. The palaeobotanical evidence provided in this study also suggests the weakness of the potential natural vegetation concept (e.g. Carrión, 2010; Chiarucci et al., 2010), particularly in complex transitional areas, such as these.
In southern Europe, Pinus identification at the species level is difficult to achieve from pollen remains, as eleven different species currently coexist. In the Iberian Peninsula, palynologists are eventually able to distinguish two groups based on their sizes and morphologies: sylvestris and pinaster (see Ramil-Rego et al., 1998; Carrión et al., 2000). In the Cantabrian Mountains, it is commonly assumed that these pollen types correspond to these two particular Pinus species, as they are the only species naturally growing today in northwestern Iberia. However, macrofossil data report the existence of additional species of highland pines (Pinus uncinata Ramond ex DC and Pinus nigra Arnold) during the Quaternary in
Site

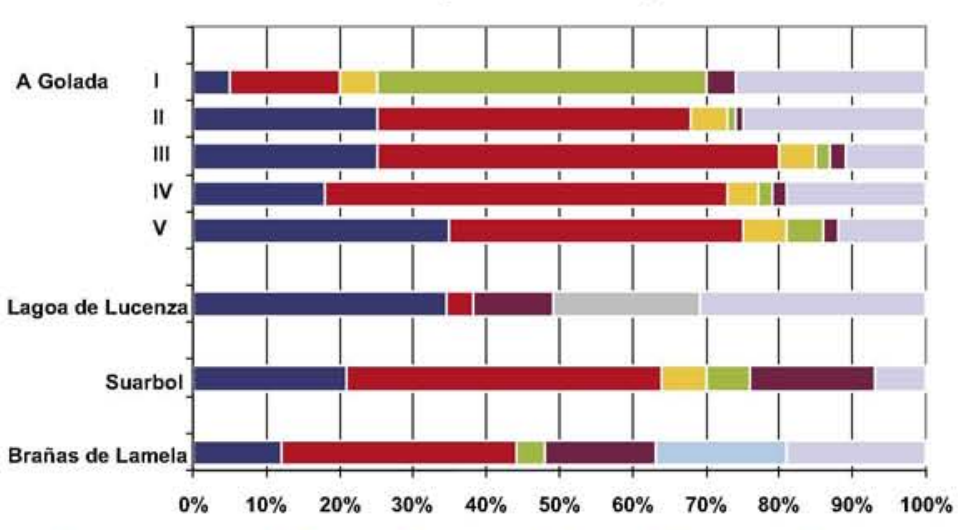

Pollen spectra (selected taxa)

Quercus tp. robur Betula Corylus Erica
Dominant taxa in pollen zones

Erica sp.
Betula sp.
Betula sp.
Betula sp
Quercus / Betula

Quercus / Salix

Betula sp

Betula sp

Poaceae Cyperaceae

Salix 밈 Others

\section{Subfossil wood evidence}

Erica sp.
Erica sp.
Hardwood / undiff
Betula sp
Quercus tp robur
Salix sp
Betula sp
Betula sp

Fig. 5. Comparison between pollen results and macrofossil data for cases in which both methods were applied. Pollen data obtained from Muñoz Sobrino et al. (1997, 2001). 
northwestern Iberia (Turner and Hannon, 1988; Roig et al., 1997; Alcalde et al., 2000). Well-preserved remains of cones (and charcoal or wood) can be distinguished to a greater degree than pollen, although the correct identification of wood from these three species of the sylvestris group (which is equivalent to what is referred to in this study as 'highland pines' and includes $P$. sylvestris, $P$. nigra and, less probably, $P$. uncinata) requires particular conditions, and the species are often impossible to separate (Schweingruber, 1990; Carcaillet and Vernet, 2001; Rubiales et al., 2008).

In the mountains of northwestern Iberia, abundant Pinus pollen has been recovered widely in western Cantabrian sediments dating to the lateglacial (ca. 17,000 years cal yr BP; Muñoz Sobrino et al., 2007). The records that cover the end of the Pleistocene indicate, as for most of Iberia, a predominant role of Pinus and Betula in the arboreal vegetation (Maldonado, 1994; Turner and Hannon, 1998. Ramil-Rego et al., 1998; Muñoz Sobrino et al., 2004, 2007; Rubiales et al., 2010). Abundant macrofossil needles of Pinus and fruits of Betula were also recorded in lateglacial sediment at the Sanabria Marsh (at an altitude of $1050 \mathrm{~m}$ asl) up until ca. 8200 radiocarbon yr BP(Turner and Hannon, 1988). P. sylvestris macrofossil needles were also recovered in lake sediments at Lago de Ajo in the Cantabrian Mountains (at an altitude of $1570 \mathrm{~m}$ asl), but only after ca. 8500 radiocarbon yr BP (McKeever, 1984; Allen et al., 1996).

Palynological evidence points to major lateglacial - Early Holocene climate change as influencing the expansion of hardwoods at the expense of pine forests, particularly in environments influenced by maritime climates. This process of change may have relied on events of autogenic succession in which competitive broadleaf trees would have displaced conifers and in response to development of milder winters as a result of increasing maritime influence, which may have hindered pine survival and recruitment in the long term, as occurred in higher latitudes (Crawford et al., 2003; Crawford, 2005). These results are in agreement with a pattern of relative dissymmetry in the presence of Pinus during the Holocene following a macroclimatic framework in which oceanic areas (those exposed to northerly and westerly winds) register this early demise (Muñoz Sobrino et al., 2007). Moreover, different patterns of land use by human groups (such as the use of fire) should not be dismissed (Allen et al., 1996; Ramil-Rego et al., 1998; Muñoz Sobrino et al., 2004). Submediterranean, south facing slopes, high altitudes, histosols and shallow soils on shady slopes and quartzites allow the existence of persistent populations of pines dating to the historic period and even the present time (Rivas-Martínez, 1964; García Antón et al., 1997; Génova, 1998; Muñoz Sobrino et al., 2003).

\subsection{Climate fluctuations and vegetation response in the Cantabrian region during the Holocene}

Palaeoclimatic data are relatively scarce for the Duero basin and the inner slopes of northern Iberia, mainly due to the absence of sedimentary deposits producing palaeo-environmental information with a strong temporal resolution. This lack of palaeoclimatic records makes necessary the use of information from lower altitudes at nearby areas. Although the climate differences are clearly discernable between mountains, middle altitudes and coastal environments, they would presumably reflect relatively similar climatic trends in term of precipitation and temperature oscillations if we assume that the North Atlantic played a major role in the climate of this region (Turner and Hannon, 1988; Muñoz Sobrino et al., 2005, 2009).

The evidence provided from a multiproxy site located in the nearby mountains (Lago Enol in the northern Cantabrian slopes) reports distinct climatic phases during the Holocene. First, a humid and warm period, peaking around $9000 \mathrm{cal} \mathrm{yr} \mathrm{BP}$, is detected. This period is followed by a tendency toward a drier climate during the mid-Holocene (ca. 8700-4650 cal yr BP) and a subsequent return to humid conditions, which coincided with the increase in anthropogenic pressure at approximately 4650-2200 cal yr BP (Moreno et al., 2011). This pattern may be compatible with those phases described before and after the 8.2 event, respectively, for middle altitude mountains from both the westernmost and easternmost Cantabrian corners (Muñoz Sobrino et al., 2005, 2009).

The information provided by biomarkers (lipid distribution and total organic carbon) in the Roñanzas peat bog (Ortiz et al., 2010) seem to show a relatively good correspondence with the preceding observations and other Iberian records on the Cantabrian coastal region; they also show the alternation of dry/humid periods during the last 8000 cal yr BP (Fig. 6). However, the episodes of dryness and humidity do not seem to be linked to other records of temperature variation (Martínez Cortizas et al., 2009).

Other available palaeo-environmental records date the importance of human activities as being responsible for large-scale changes in the environment from $6000 \mathrm{cal}$ yr BP onward (Muñoz Sobrino et al., 2005; Martínez Cortizas et al., 2009; López-Merino et al., 2010; Martín-Chivelet et al., 2011). From approximately this period, palaeo-environmental records show difficulty in distinguishing the role of climate and human activity, although evidence of climatic variations into the Neolithic and Chalcolithic have been interpreted from pollen sequences (Allen et al., 1996; Muñoz Sobrino et al., 2005) and geochemical signals (Fábregas Valcarce et al., 2003). Further, complex synergistic (or antagonistic) interactions between climate-induced changes and the effects of widespread alterations in land use makes investigating the causes of vegetation change complicated. However, in general terms, pollen and other palaeoclimatic archives document that, in the Cantabrian Range, well-established vegetation, generally dating from the early Holocene, shows only minor change (with the notable exception of Fagus, which quickly expanded during the last millennia), which may be mainly assigned to the climatic oscillations of the mid-to-late Holocene (Allen et al., 1996; Muñoz Sobrino et al., 1997, 2005, 2009; Moreno et al., 2011; Carrión et al., 2010b).

\subsection{Impact of late Holocene anthropogenic activity on vegetation history}

Available data suggest that a large part of the northern Iberian territories had been subject to significant deforestation by the midHolocene. The appearance of agriculture and domestic cattle has been well documented in the Cantabrian area since the beginning of the 7th millennium cal yr BP (Ramil-Rego and Aira Rodríguez, 1993; Arias and Altuna, 1999) and has been solidly established as a subsistence strategy throughout the area during the following two millennia (Arias, 1999; Arias et al., 1999). The combination of studies of pollen and non-pollen palynomorphs reinforce the information obtained from palaeozoological records, which have recorded pastoralism and agriculture (at least in the lowlands) by ca. 7000 cal yr BP (López-Merino et al., 2010). Those studies, combined with macrocharcoal identification, suggest the spread of fire, linked to pastoral activities and local changes in vegetation composition, since ca. $6000 \mathrm{cal} \mathrm{yr} \mathrm{BP}$ in some lowlands of the Atlantic coastal area (Carrión et al., 2010a).

In the innermost mountains of northwestern lberia, a number of pollen diagrams show noticeable changes in the vegetation composition when unequivocal indicators of anthropogenic disturbance appear (i.e., Cerealia, Plantago, Rumex, Asphodelus; Allen et al., 1996; Muñoz Sobrino et al., 2005; Carrión et al., 2010a). Nevertheless, the ambivalent responses of some species may obscure the changes in the forest due to such disturbances, instead 


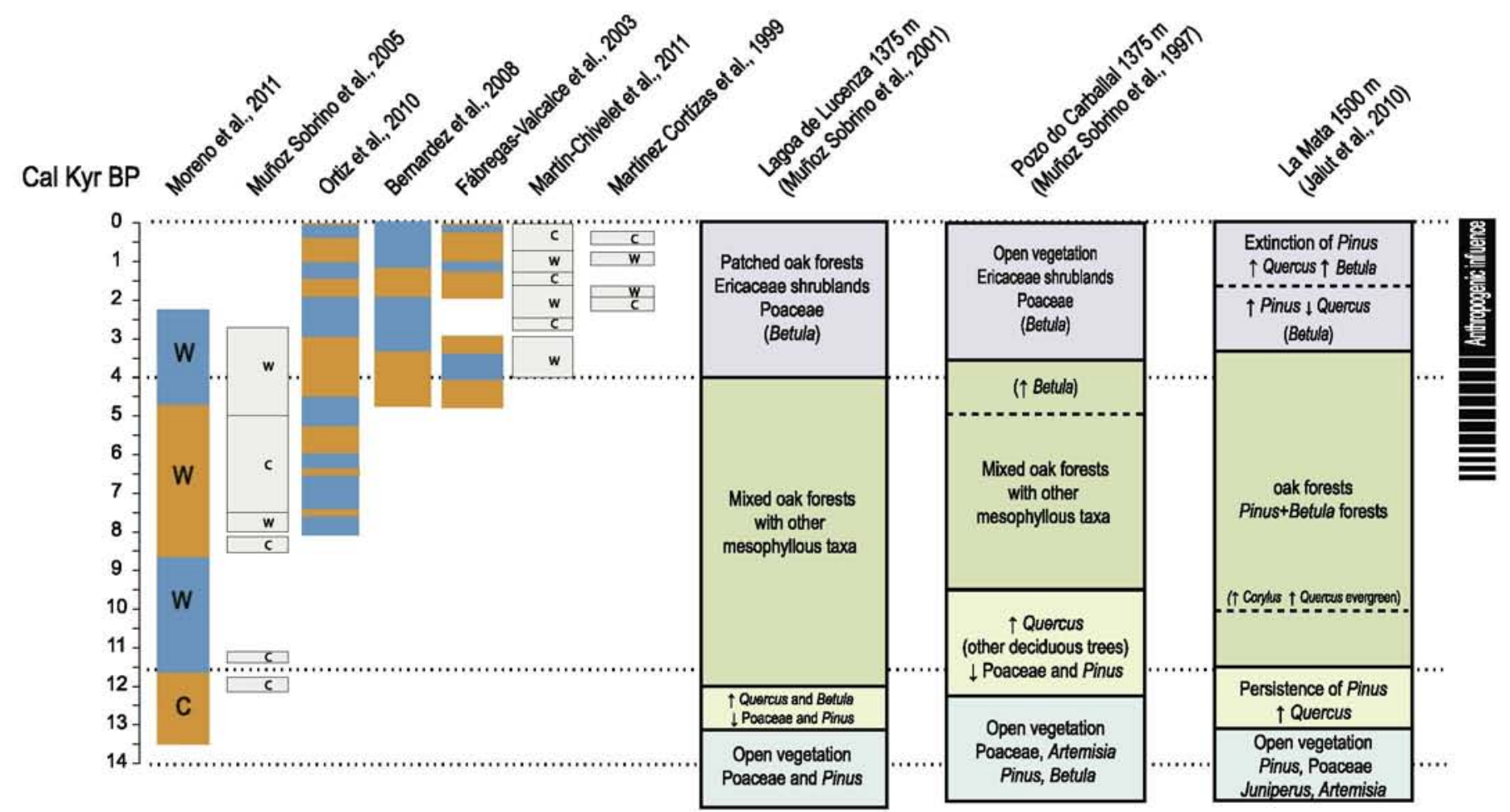

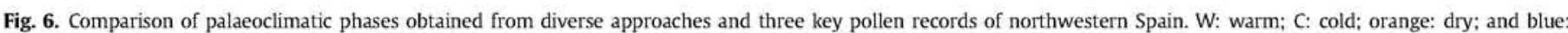
humid. (For interpretation of the references to colour in this figure legend, the reader is referred to the web version of this article.)

indicating a relative resilience to them. This is the case for Betula, one of the most heavily represented trees in the macrofossil record during the late Holocene in the westernmost mountains, which may have played distinct roles in Iberian landscapes at the end of the Holocene.

Moderate-to-high percentages of Betula have been found in this area since the lateglacial, continuing to the onset of the Holocene at altitudes of 1200 to $1400 \mathrm{~m}$ asl. Wood samples of arboreal Betula have also been identified from mid- to late Holocene sites in the westernmost mountains of the Cantabrian Range, most particularly at Suárbol (Muñoz Sobrino et al., 1997), A Golada (ca. 3600 cal yr BP) and, at later dates, Brañas de Lamela and Suárbol (ca. 1100 cal yr $\mathrm{BP}$ ). Interpretation of Betula is challenging, however, as it grows either as part of a stable, late succesional forest, as well as in early successional phases (Muñoz Sobrino et al., 1997). Betula is resistant to greater acidic and damp soil conditions that are characteristic of active mires (where the findings were made), but it is also known to be one of the most tolerant arboreal elements to dry and cold environments and it is commonly found as the only broadleaved tree at high elevation, frequently at treeline (Costa et al., 1997). Furthermore, its potential as a pioneer species suggests it can be favoured after fire (Costa et al., 1997; Sevilla, 2008). Its tolerance to a moderate recurrence of fires has been suggested by long-term records in mountainous regions of Iberia (Stevenson, 2000; Morales-Molino et al., 2011), and a regression of other wellestablished forests (such as those of Quercus and/or Pinus) is usually correlated with the expansion of birch during the mid- and late Holocene (Allen et al., 1996; Muñoz Sobrino et al., 1997). Birch may have also acted in the western corner of the Cantabrian area as a late successional tree, i.e., a role similar to that described for beech in the eastern Cantabrian Range (Muñoz Sobrino et al., 2009).

The finding of charred remains of deciduous Quercus and Cytisus at the Balouta site has been dated at $4850 \mathrm{cal} \mathrm{yr} \mathrm{BP,} \mathrm{which} \mathrm{is}$ approximately the same moment as the beginning of the cereal pollen curve recorded, at similar altitudes, in Sierra de Ancares (Muñoz Sobrino et al., 1997). Furthermore, the pollen evidence suggests that, at this time, a regional retraction of deciduous Quercus began together with the synchronic expansion of Betula with heaths.

These dynamics would reflect a probable response after the occurrence of fires, which mainly affected the lower valleys and southern slopes (Muñoz Sobrino et al., 1997). Thus, this early phase in Betula expansion (peaking at ca. $3300 \mathrm{cal} \mathrm{yr} \mathrm{BP)} \mathrm{might}$ also be reflective of a better stage of upland oceanic forests (where birch finds its optimum environment) and a regional treeline that was located above its current limit (Muñoz Sobrino et al., 2003). Later, a climatic deterioration during the last third of the Holocene has been recorded (Fig. 5), but the regional expansion of Betula includes a second maximum registered at ca. $1100 \mathrm{cal} \mathrm{yr}$ BP (Muñoz Sobrino et al., 1997). Heaths notably expanded between both birch maxima and during the last millennia. The pollen sequences reveal an upward progression of crops; frequently, the beginning of a continuous cereal-type curve (reflecting local occurrence) is synchronic with either the decrease in the total arboreal pollen or with the maximum pollen percentages of Betula. This finding suggests that anthropogenic activity could be, in some cases, responsible for the dominance of birch at middle and high altitudes (Muñoz Sobrino et al., 1997; Santos, 2004). The occurrence of wood remains of Erica in A Golada during the last 1000 years could reinforce the possible role of fires in the shaping of the vegetation of the region while climate conditions deteriorated.

\subsection{The fate of pines at the late Holocene in NW Iberia: humans,} fire impact and shrubland expansion

The continuous distribution of pine megafossils along the Cantabrian Range, together with palynological data (e.g. Jalut et al., 
2010) depicts a probable continuous area for Pinus gr. sylvestris during a large part of the Holocene. Furthermore, the existence of a robust dataset of archaeobotanical data from other sites of northern Portugal (Figueiral and Carcaillet, 2005) and other isolated points at the inner section of the Duero basin (archaeological data dating to the Iron age and natural, living specimens, Hernández et al., 2011) supports the idea that the distribution area of this group of pines has suffered a dramatic demise during the last millennia.

The recorded fate of highland pines ( $P$. sylvestris and probably $P$. nigra) during the late Holocene in the areas where it was able to persist across the first half of the Holocene may also correspond to the intensification of human activity in the territory (Rubiales et al., in press). In the records from the central part of the mountain range, the episodes of Pinus decline include the expansion of Erica and, rarely, hardwoods take part in a woodland expansion (Menéndez Amor and Florschütz, 1961; Mariscal, 1983, 1986; Salas, 1991). A parallel pattern has been found in some other deposits from the western part of the Cantabrian Range (Jalut et al., 2010) and near mountains, such as Cabrera (Janssen, 1996), Segundera (Allen et al., 1996; Muñoz Sobrino et al., 2004) and Teleno (MoralesMolino et al., 2011). Highlands (areas over $1600 \mathrm{~m}$ a.s.l., which would roughly correspond to a potential belt with pines) might have been strategically preferred by human groups for growing livestock since the Neolithic period (ca. 6000 radiocarbon yr BP onward) because pastures located at these altitudes would have been more productive during the summer than pastures in the lowlands (Jarman et al., 1982; Díez Castillo, 1998; Fontana and Guerreschi, 2003). Furthermore, the active selection of conifers by humans during the historical period, due to their technical properties, might have aggravated this process of disappearance (Rubiales et al., 2011).

The succession of different historical periods in which this pattern of land use was intensified (including the Celt migration, Roman domination, Middle Age overpopulation caused by the Moorish advance and the flourishing age of the wool trade and transhumance) could have restricted pinewoods to specific locations that were protected from fire and had unfavourable conditions for the development of other species, (e.g., steep slopes surrounded by rocky environments). The Lillo pinewood remained a valuable resource of wood during the last centuries and especially during the wood shortages that may have existed after the $\sim 500 \mathrm{yr}$ of pine scarcity recorded in the pollen site of Lillo (García Antón et al., 1997). The map dated 1683 of a lawsuit over the ownership of the Lillo pinewood (Fig. 7) shows that the surroundings of this forest were at that time deforested and transformed into pastures to support transhumant livestock.

Features derived from life-history traits do not favour Iberian highland pines over other Cantabrian species under a regime of frequent fire. Pines are obligate seeders, a disadvantage over resprouters (i.e., $Q$ pyrenaica) and their ability to occupy geomorphic fire-shelters such as wetlands and screes, is limited compared to other tree genera (i.e. Quercus, Sorbus, Fagus, Sevilla, 2008). A paradox for pine persists. In northern latitudes highland pines depend on disturbances (mainly fire) to regenerate (Agee, 1998), allowing the long-term persistence of populations; at their southern edge, these disturbances now constitute a serious threat to their survival, as reflected by their fire ecology (Trabaud and Campant, 1991; Retana et al., 2002; Rodrigo et al., 2004). The reasons for its poorer survival in the south, at the trailing edge of its

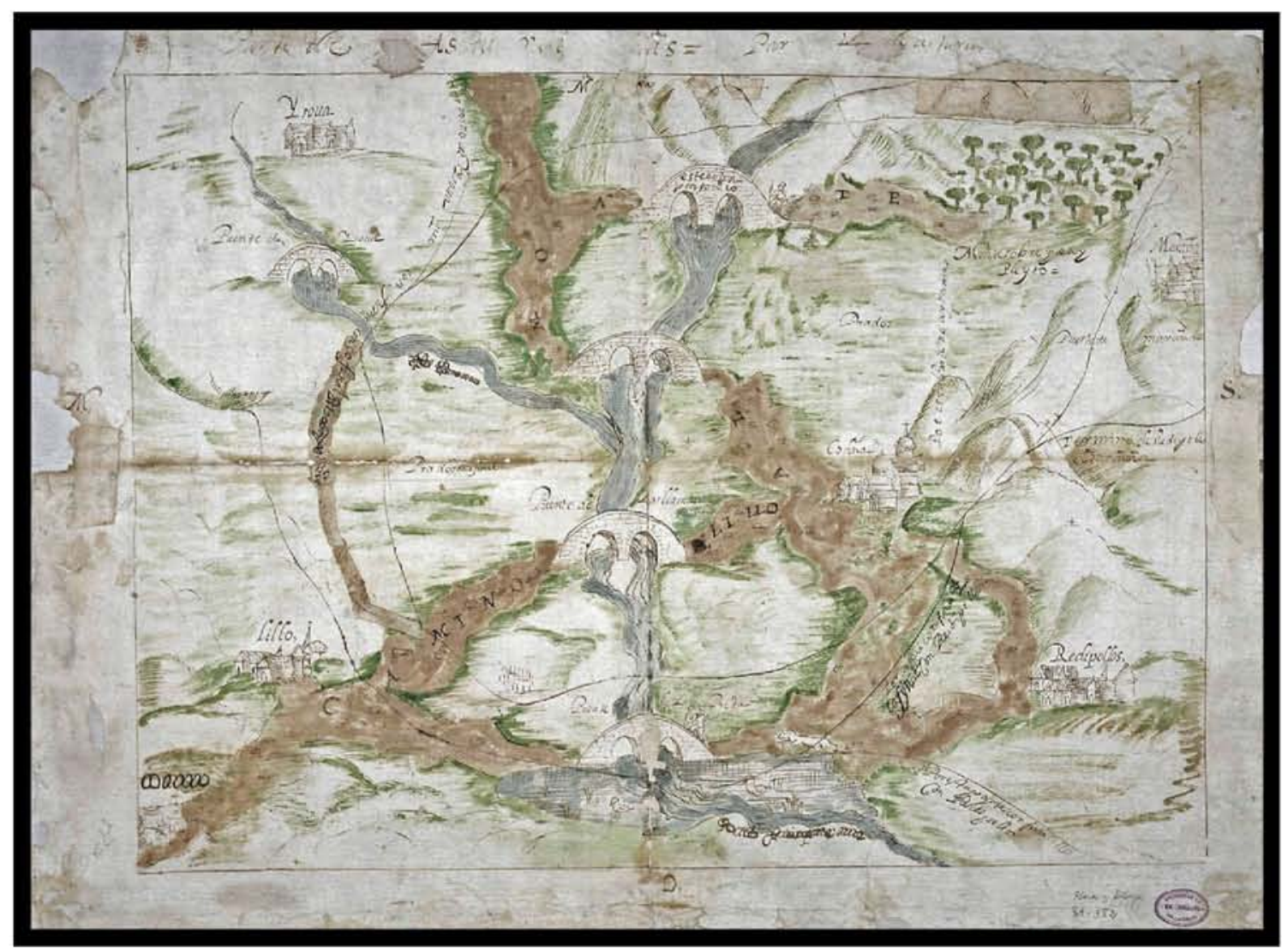

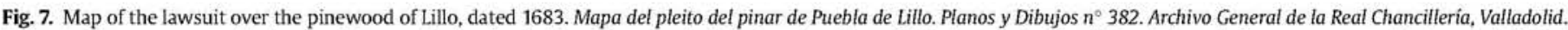

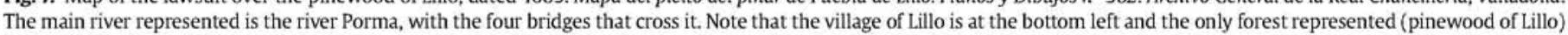
is situated at the top right (Monte sobre que ay Pleyto). 
distribution area are complicated, but may include higher fire frequencies, different sizes and intensities (e.g. higher frequency of crown fires). Most importantly, the likely combination with pastoralism might have resulted in radically different abilities to regenerate.

The presence of pines and pinewoods in the central and western Cantabrian Range during several historical periods has been reported from the analysis of document-derived datasets and toponyms (Manuel and Gil, 2001; Manuel et al., 2003; Díaz-Fernández and Gil, 1996; Ezquerra and Gil, 2004). Some of these historical data and toponyms refer to the environments surrounding the sites where macro-remains have been found. The name of the valley where the Valdelugueros site is located is perhaps one of the clearest examples: Riopinos means, literally, "river (of) pines"; the name was documented at least four centuries ago, and this name is also frequently found in the surrounding valleys. Several other references to pines have been reported in the historical literature. In a document dated to $928 \mathrm{AD}$, Pineto is referred to in the eastneighbour valley (Minguez, 1976). In the same valley as the Torrestio site, the name of a present-day village is Pino (i.e., pine), which was also found in a document dated to $1181 \mathrm{AD}$ (Valcarce, 1986). Some documents connect the pine toponym with the continuing presence of pinewoods in a direct way, as was the case for a will dated to $932 \mathrm{AD}$ from the central part of the Cantabrian Range: "et in pineda la maiada de Fontaniellas cum suis pascuis [...] et ex alia parte del pinar...", (and in pineda, the fold of Fontaniellas with its pastures (...) and the other side of the pinewood...), Montenegro, 1991. Analogous references for both the southern and northern slopes can be found almost everywhere after appropriate searches (Heredia, 1900; Floriano, 1949; Álvarez, 1994; Ruhstaller, 1995). Some references are not related to the pine name but instead to some of its uses, such as the Pegueras River, the name of which is related to pitch extraction in the Esla valley (López, 1786).

Using a synthetic approach, a geographical compendium from the 19th century summarises the history of pinewoods in the province of Leon, which is currently supported by our findings: “... the pine tree is already almost unknown in this province, though it previously predominated here over all the other wood types as demonstrated by the skeleton of the most important and ancient buildings of the capital..." (Madoz, 1845-1850). Even at that time, many scattered stands, isolated trees or pine stumps might have been found in the Cantabrian Range in addition to the remaining forests that have survived until the present time, as registered by other authors (Urquijo, 1989; Ezquerra, 2007).

\section{Concluding remarks}

One of the more remarkable findings of this study is the fact that all of the megafossils recovered in the central and western parts of the Cantabrian Range have been identified as Pinus gr sylvestris, while pine remains are absent from macrofossil data from the western edge of the Cantabrian Range (Ancares and Courel Mountains), and only low percentages were detected in the pollen data. This disappearance has been the primary reason that pine has not been considered as part of the natural vegetation there. However, the megafossils that we present here increase the evidence supporting the idea that potential natural vegetation is biased by a subjective perception, at least in most areas, as previously suggested in other locations (Pardo and Gil, 2005; ValbuenaCarabaña et al., 2010; Rubiales et al., 2010).

Aside from possible differences in the type of deposit, some ecological implications of these findings must be considered. Our evidence suggests that, since the onset of the Holocene, pinewoods have done better in more extreme climates, where their ability to withstand broadleaved tree invasions has been the greatest.
Furthermore, topographic considerations may have been important. Not only do gradients of continentality increase from west to east, but also does the mean altitude, resulting in colder climate conditions. This may explain why all recovered pine remains occur from sites over $1400 \mathrm{~m}$ asl. This is important, because no deposits analyzed in the west reach that altitude. Macrofossil $P$. sylvestris from Lago de Ajo ( $1570 \mathrm{~m}$ asl) are recorded in the early Holocene and in Sanabria, which is located to the southwest and at a lower altitude (ca.1050 m asl), P. sylvestris macrofossils are only found in the lateglacial. Moreover, the physiography of the western districts (which are predominantly hilly) turns to a rugged rocky relief to the east, which implies the existence of thinner and poorer soils (which are less suitable to species that are characteristic of later stages of vegetal succession) and a better defence against fire. All of these attributes shape a better scenario for the long-term maintenance of pinewoods, which is superimposed on the possible differences in the use of fire by humans.

\section{Acknowledgments}

This research was funded by the Ministerio de Ciencia e Innovación (grants CGL2008-06005 BOS and CGL2009-0698 BOS) and the Junta de Castilla y León. The authors are grateful to their colleagues and forest rangers of León who have actively participated in the fieldwork leading to this research, and to Jesús Alonso and Paco Masedo for processing some of the studied materials. They would like to thank Mariano Torre, Froilán Sevilla for his encouragement, Daniel Pinto, Marta Monsalve, Ignacio Antón, Carlos Morla and our colleagues at the U.D. Botánica (E.T.S.I. Montes) for their help and support, and the Ministerio de Cultura (Archivo General de la Real Chancillería, Valladolid) for Fig. 7. Thanks also to R. Scott Anderson and an anonymous reviewer for generous suggestions and constructive comments.

\section{References}

Agee, J.K., 1998. Fire and pine ecosystems. In: Richardson, D.M. (Ed.), Ecology and Biogeography of Pinus. Cambridge University Press, pp. 193-218.

Alcalde, C., García-Amorena, I., Gómez, F., Maldonado, J., Morla, C., Postigo, J.M. 2000. Estudio de los macrorrestos vegetales del yacimiento de Lomilla (Aguilar de Campoo, Palencia, Spain). Anales Jard. Bot. Madrid 59, 101-112.

Alcalde, C., García-Amorena, 1., García Alvarez, S., García Calvo, D., García García, R., Génova, M., Gil Borrell, P., Gómez Manzaneque, F., Maldonado, J., Morla, C., 2006. Contribución de la Paleofitogeografia a la interpretación del paisaje vegetal ibérico. Invest. Agrar. Sist. Recur. For. 15, 40-54.

Allen, J.R.M., Huntley, B., Watts, W.A., 1996. The vegetation and climate of northwest Iberian over the last 14000 yr. J. Quat. Sci. 11 (2), 125-147.

Álvarez, M.A., 1994. Diplomática asturleonesa. Terminología Toponímica. Universidad de León, León.

Andrade, A., Valdeolmillos, A., Ruíz-Zapata, B., 1994. Modern pollen spectra and contemporary vegetation in the Paramera Mountain range (Ávila, Spain). Rev. Palaeobot. Palynol. 82, 127-139.

Arias, P., 1999. The origins of the neolithic along the Atlantic coast of continental Europe: a survey. J. World Prehist. 13, 403-464.

Arias, P., Altuna, J., 1999. Nuevas dataciones absolutas para el Neolítico de la cueva de Arenaza (Bizkaia). Munibe (Antropologia-Arkeologia) 51, 131-141.

Arias, P., Altuna, J., Armendariz, A., González Urquijo, J.E., Ibáñez Estévez, J.J., Ontañón Peredo, R., Zapata, L, 1999. Nuevas aportaciones al conocimiento de las primeras sociedades productoras en la región Cantábrica. In: Bernabeu Aubán, J., Orozco Köhler, T. (Eds.). Actes del II Congrés del Neolític a la Península Ibèrica, Universitat de València 7-9 d'Abril, 1999, pp. 549-557.

Birks, H.J.B., 1996. Contributions of Quaternary palaeoecology to nature conservation. J. Veg. Sci. 7, 89-98.

Birks, H.H., 2003. The importance of plant macrofossils in the reconstruction of lateglacial vegetation and climate: examples from Scotland, western Norway, and Minnesota, USA. Quat. Sci. Rev. 22, 453-473.

Birks, H.H., Birks, H.J.B., 2000. Future uses of pollen analysis must include plant macrofossils. J. Biogeogr. 27, 31-35.

Carcaillet, C., Muller, S.D., 2005. Holocene tree-limit and distribution of Abies alba in the French Alps: anthropogenic or climatic changes? Boreas 34, 468-476.

Carcaillet, C., Vernet, J.L., 2001. Comments on "The full-glacial forests of central and southeastern Europe" (Willis et al., 2000). Quaternary Research 55, 385-387.

Carrión, J.S., 2002. Patterns and processes of Late Quaternary environmental change in a Montane region of southwestern Europe. Quat. Sci. Rev. 21, 2047-2066. 
Carrión, J.S., 2010. The concepts of potential natural vegetation (PNV) and other abstractions (trying to pick up fish with wet hands). J. Biogeogr. 37, 2213-2215.

Carrión, J.S., Navarro, C., Navarro, J., Munuera, M., 2000. The distribution of cluster pine (Pinus pinaster) in Spain as derived from palaeoecological data: relationships with phytosociological classification. Holocene 10 (2), 243-252.

Carrión, Y., Kaal, J., López-Saez, J.A., López-Merino, L., Martínez-Cortizas, A., 2010a Holocene vegetation changes in NW lberia revealed by anthracological and palynological records from a colluvial soil. Holocene 20,53-60.

Carrión, J.S., Fernández, S., González-Sampériz, P., Gil-Romera, G., Badal, E., CarriónMarco, Y., López-Merino, L., López-Sáez, J.A., Fierro, E., Burjachs, F., 2010b. Expected trends and surprises in the lateglacial and Holocene vegetation history of the Iberian Peninsula and Balearic Islands. Rev. Palaeobot. Palynol. 162, 458-475.

Chiarucci, A., Araújo, M.B., Decoq, G., Beierkuhnlein, C., Fernández-Palacios, J.M. 2010. The concept of potential natural vegetation: an epitaph? J. Veg. Sci. 21 (6) $1172-1178$.

Costa, M., Morla, C., Sainz, H., 1992. Datos sobre las comunidades de caméfitos espinosos en los macizos meridionales galaicos (NW España). Lazaroa 13, $139-147$

Costa, M., Morla, C., Sainz, H. (Eds.), 1997. Los bosques ibéricos. Una interpretación geobotánica. Planeta, Barcelona.

Crawford, R.M.M., 2005. Trees by the sea: advantages and disadvantages of oceanic climates. Biol. Environ. 105, 129-139

Crawford, R.M.M., Jeffree, C.E., Rees, W.G., 2003. Paludification and forest retreat in northern oceanic environments. Ann. Bot. 91, 213-226.

Díaz-Fernández, P., Gil, L., 1996. Datos histórico-geográficos sobre la presencia de pinares en la Cordillera Cantábrica. In: Guitian, L., González, R.L. (Eds.), Actividad humana y cambios recientes en el paisaje. Consellería de Cultura-Xunta de Galicia, Santiago de Compostela, pp. 55-68.

Díez Castillo, A., 1998. Early Holocene occupations in high Cantabrian mountains (Spain). Beyond the lithics: Mesolithic people in Europe. Society for American Archaeology, Annual Meeting.

Ezquerra, F.J., 2007. El uso atávico del fuego y la extinción local de los pinares cantábricos. In: Gill, L., Torre, M. (Eds.), Atlas Forestal de Castilla y León. Junta de Castilla y León, Valladolid.

Ezquerra, F.J., Gil, L., 2004. La transformación histórica del paisaje forestal en la Comunidad de Cantabria. Ministerio de Medio Ambiente, Madrid.

Fábregas Valcarce, R., Martinéz Cortizas, A., Blanco Chao, R., Chesworth, W., 2003. Environmental change and social dynamics in the second-third millenium $B C$ in NW Iberia. J. Archaeol. Sci. 30, 859-871.

Figueiral, I., Carcaillet, C., 2005. A review of Late Pleistocene and Holocene biogeography of highland Mediterranean pines (Pinus type sylvestris) in Portugal, based on wood charcoal. Quat. Sci. Rev. 24, 2466-2476.

Floriano, A.C., 1949. Diplomática española del período astur. Estudio de las fuentes documentales del reino de Asturias (718-910), 1. Imprenta La Cruz, Oviedo.

Fontana, F., Guerreschi, A., 2003. Highland occupation in the Southern Alps. In: Larsson, L. (Ed.), Mesolithic on the Move. Proceedings of the 6th International Conference on the Mesolithic in Europe. Stockholm, 4-8 September 2000. Oxbow Books, Oxford (England), pp. 96-102.

Froyd, C.A., 2005. Fossil stomata reveal early pine presence in Scotland: implications for postglacial colonization analyses. Ecology 86, 579-586.

García, L., Guindeo, A., 1988. Anatomía e identificación de las maderas de coníferas españolas. AITIM, Madrid.

García Antón, M., Franco, F., Maldonado, J., Morla, C., Sainz, H., 1997. New data concerning the evolution of the vegetation in the Lillo pinewood (León, Spain). J. Biogeogr. 24, 929-934.

García Antón, M., Gil Romera, G., Pagés, J.L., Alonso Millán, A., 2006. The Holocene pollen record in the Villaviciosa Estuary (Asturias, North Spain). Paleogeogr Paleoclimatol. Paleoecol. 237, 280-292.

Génova, M., 1998. Estudio de los anillos de crecimiento y su relación con las variables meteorológicas en el pinar de Lillo (León). Ecología 12, 237-250.

Gillson, L., Willis, K.J., 2004. 'As Earth's testimonies tell': wilderness conservation in a changing world. Ecol Lett 7, 990-998.

Gómez, A., Lunt, D.H., 2007. Refugia within refugia: patterns of phylogeographic concordance in the lberian Peninsula. In: Weiss, S., Ferrand, N. (Eds.), Phylogeography of Southern European Refugia. Springer, Dordrecht, The Netherlands.

Gómez-Orellana, L., Ramil Rego, P., Muñoz Sobrino, C., 2007. The Würm in NW Iberia, a pollen record from area Longa (Galicia). Quatern. Res. 67, 438-452.

Greguss, P., 1955. Identification of Living Gymnosperms on the Basis of Xylotomy. Akadémiai Kiado, Budapest.

Gutierrez Elorza, M., 1994. Geomorfologia de Espana. Rueda, Madrid.

Heredia, A.G.de., 1900. "Proyecto de Ordenación de los montes "La Boria", de Boca de Huérgano; "Valdeguiza", de Siero, Villa y "Valdecia" de Villafrea; "Avoces Olloroso" de Éscaro y "Hormas y Agregados" de Riaño", Archivo Histórico Provincial de León.

Hernández, L., Rubiales, J.M., Morales-Molino, C., Romero, F., Sanz, C., Gómez Manzaneque, F., 2011. Reconstructing forest history from archaeological data: a case study in the Duero basin assessing the origin of controversial forests and the loss of tree populations of great biogeographical interest. Forest Ecol. Manag. 261, 1178-1187.

IUCN, 2010. IUCN Red List of Threatened Species. Version 2010.4. http://www. iucnredlist.org (accessed 10.11.10.).

Izco, J., Ramil-Rego, P., Díaz Varela, R., 2004. Lista roja de la flora vascular gallega. In: Rodríguez, F. (Ed) Galicia, Naturaleza. Botánica III. Hercules Ediciones, La Coruña.

Jacquiot, C., 1955. Atlas d'anatomie des bois des conifères. Centre Technique du Bois, Paris.
Jalut, G., Michels, V.T., Dedoubat, J.J., Otto, T., Ezquerra, J., Fontugne, M., Belet, J.M., Bonnet, L., de Celis, A.G., Redondo-Vega, J.M., 2010. Palaeoenvironmental studies in NW Iberia (Cantabrian range): vegetation history and synthetic approach of the last deglaciation phases in the western Mediterranean. Paleogeogr. Paleoclimatol. Paleoecol. 297, 330-350.

Janssen, C.R., 1996. Aspects of vegetation development in the Sierra Cabrera Baja, NW-Cantabria, Spain, as part of a long-term project in the medium high mountains of western and southwestern Europe. In: Ramil-Rego, P., Fernández Rodriguez, C., Rodriguez Guitiân, M. (Eds.), Biogeografia Pleistocena-Holocena de la Península Ibérica. Consellería de Cultura-Xunta de Galicia, Santiago de Compostela, pp. 183-197.

Jarman, M.R., Bailey, G.N., Jarman, H.N., 1982. Early European Agricultures. Its Foundations and Development. Cambridge University Press, London.

Kullman, L., 2008. Early postglacial appearance of tree species in northern Scandinavia: review and perspective. Quat. Sci. Rev. 27, 2467-2472.

Llamas, F., Acedo, C., Lence, C., Alonso, R., Molina, A., Castro, V., 2007. Flora cantábrica de interés en Castilla y León. Naturalia Cantabricae 3, 57-68.

López, T., 1786. Mapa geográfico de una parte de la provincia de León. Madrid.

López Merino, L., 2009. Paleoambiente y antropización en Asturias durante el Holoceno" Tesis doctoral. Facultad de Ciencias, Departamento de Ecología, Universidad Autónoma de Madrid

López-Merino, L., Martínez Cortizas, A., López-Sáez, J.A., 2010. Early agriculture and palaeoenvironmental history in the North of the Iberian Peninsula: a multiproxy analysis of the Monte Areo mire (Asturias, Spain). J. Archaeol. Sci. 37, $1978-1988$

Madoz, P., 1845-1850. Diccionario geográfico estatddístico histórico de España y sus posesiones de ultramar. Madrid, Spain.

Maldonado, F.J., 1994. Evolución tardiglaciar y holocena de los macizos del Noroeste Peninsular. Ph.D. Thesis, Escuela Técnica Superior de Ingenieros de Montes. Universidad Politécnica de Madrid.

Manuel, C., Gil, L., 2001. La transformación histórica del paisaje forestal de Galicia. Ministerio de Medio Ambiente, Madrid.

Manuel, C., Díaz-Fernández, P., Gill, L., 2003. La transformación histórica del paisaje forestal en Asturias. Ministerio de Medio Ambiente, Madrid.

Mariscal, B., 1983. Estudio polínico de la turbera del Cueto de la Avellanosa, Polaciones (Cantabria). Cuadernos Geol. Laxe, 205-222.

Mariscal, B., 1986. Análisis polínico de la turbera del pico del Sertal. Reconstrucción de la Paleoflora y de la Paleoclimatología durante el Holoceno en la zona oriental de la Cordillera Cantábrica. In: López Vera, F. (Ed.), Quaternary Climate in the Western Mediterranean. Universidad Autónoma de Madrid, pp. 205-220.

Martín-Chivelet, J., Muñoz-García, M.B., Edward, R.L., Turrero, M.J., Ortega, A.I., 2011. Land surface temperature changes in Northern Iberia since $4000 \mathrm{yr} \mathrm{BP}$, based on $\delta^{13} \mathrm{C}$ of speleothems. Global Planet. Change 77, 1-12.

Martínez Cortizas, A., Costa-Casais, M., López-Sáez, J.A., 2009. Environmental change in NW Iberia between 7000 and 500 cal. BC. Quatern. Int. 200, 77-89.

McKeever, M. 1984. Comparitive palynological studies of two lake sites in western Ireland and northwestern Spain. MSc thesis. Trinity College, Dublin.

Menéndez Amor, J., Florschütz, F., 1961. Contribución al conocimiento de la historia de la vegetación en España durante el Cuaternario. Resultado del análisis palinológico de algunas series de muestras de turba, arcilla y otros sedimentos en los alrededores de Puebla de Sanabria (Zamora). Est. Geol. 17, 83-99.

Minguez, J.M., 1976. Colección Diplomática del Monasterio de Sahagún (Siglos IX-X). Caja de Ahorros y Monte de Piedad de León y Archivo Histórico Diocesano de León, León.

Moares, C., Martínez Cortizas, A., Macias Vazquez, F., 1996. Suelos con fragipán en el valle glaciar de Balouta (Sierra de Ancares, Lugo-León): significado paleoambiental. In: Pérez Alberti, A Martini, P., Chesworth, W Martínez Cortizas, A (Eds.), Dinámica y evolución de medios cuaternarios. Xunta de Galicia. Consellería de Cultura, pp. 227-241.

Montenegro, J., 1991. Colección Diplomática de Santa María de Piasca. Consejería de Cultura, Educación y Deporte. Diputación Regional de Cantabria, Santander

Morales-Molino, C., García Antón, M., Morla, C., 2011. Late Holocene vegetation dynamics on an Atlantic-Mediterranean mountain in NW Iberia. Paleogeogr. Paleoclimatol. Paleoecol. 302, 323-337.

Moreno, A., López-Merino, L., Leira, M., Marco-Barba, J., González-Sampériz, P., ValeroGarcés, B.L., López-Sáez, J.A., Santos, L., Mata, P., Ito, E., 2011. Revealing the last 13,500 years of environmental history from the multiproxy record of a mountain lake (Lago Enol, northern Iberian Peninsula). J. Palaeolimnol. 46, 327-349.

Muñoz Sobrino, C., Ramil-Rego, P., Rodríguez Guitian, M., 1997. Upland vegetation in the north-west Iberian Peninsula after the last glaciation: forest history and deforestation dynamics. Veget. Hist. Archaeobot 6, 215-233.

Muñoz Sobrino, C., Ramil-Rego, P., Gómez-Orellana, L., 2003. La vegetación postglaciar en la vertiente meridional del Macizo del Mampodre (Sector Central de la Cordillera Cantábrica). Polen 13, 31-44.

Muñoz Sobrino, C., Ramil-Rego, P., Gómez-Orellana, L., Ferreiro da Costa, J., Díaz Varela, R.A., 2009. Climatic and human effects on the post-glacial dynamics of Fagus sylvatica L. in NW Iberia. Plant. Ecol. 203, 317-340.

Muñoz Sobrino, C., Ramil-Rego, P., Guitián, M.A.R, 2001. Vegetation in the mountains of northwest lberia during the last glacial-interglacial transition. Veg. Hist. Archaeobot 10, 7-21.

Muñoz Sobrino, C., Ramil Rego, P., Gómez Orellana, L., 2004. Vegetation of the Lago de Sanabria area (NW Iberia) since the end of the Pleistocene: a palaeoecological reconstruction on the basis of two new pollen sequences. Veg. Hist. Archaeobot $13,1-22$. 
Muñoz Sobrino, C., Ramil-Rego, P., Gomez-Orellana, L., Varela, R.A.D., 2005. Palynological data on major Holocene climatic events in NW Iberia. Boreas 34 $381-400$.

Muñoz Sobrino, C., Ramil-Rego, P., Gomez-Orellana, L., 2007. Late Würm and early Holocene in the mountains of northwest Iberia: biostratigraphy, chronology and tree colonization. Veg. Hist. Archaeobot 16, 223-240.

Ninyerola, M., Pons, X., Roure, J.M., 2005. Atlas Climático Digital de la Península Ibérica. Metodología y aplicaciones en bioclimatología y geobotánica. Universidad Autónoma de Barcelona, Bellaterra.

Ortiz, J.E., Gallego, J.L.R., Torres, T., Díaz-Bautista, A., Sierra, C., 2010. Palaeoenvironmental reconstruction of Northern Spain during the last $8000 \mathrm{cal}$ yr BP based on the biomarker content of the Roñanzas peat bog (Asturias). Org. Geochem. 41, 454-466.

Pardo, F., Gil, L., 2005. The impact of traditional land use on woodlands: a case study in the Spanish Central System. J. Hist. Geogr. 31, 390-408.

Peraza, C., 1964. Estudio de las maderas de coníferas españolas y de la zona norte de Marruecos, Ministerio de Agricultura. Instituto Forestal de Investigaciones y Experiencias, Madrid.

Puente García, E., Penas Merino, A., Fombella Blanco, M.A., Andrade Olalla, A., Alonso Herrero, E., Matías Rodríguez, R., García-Rovés Fernández, E., 1998 Correlación entre la vegetación actual y el espectro polínico de la turbera del Puerto de San Isidro (León). Palinología: Diversidad y Aplicaciones, 109-116.

Ramil-Rego, P., Aira Rodríguez, M.J., 1993. A palaeocarpological study of Neolithic and Bronze Age levels of the Buraco da Pala rock-shelter (Bragança, Portugal). Veg. Hist. Archaeobot. 2, 163-172.

Ramil-Rego, P., Muñoz Sobrino, C., Rodríguez-Guitiân, M., Gómez-Orellana, L., 1998. Differences in the vegetation of the north Iberian Peninsula during the last 16,000 years. Plant. Ecol. 138, 41-62.

Reimer, P.J., Baillie, M.G.L., Bard, E., Bayliss, A., Beck, J.W., Blackwell, P.G., Bronk Ramsey, C., Buck, C.E., Burr, G.S., Edwards, R.L., Friedrich, M., Grootes, P.M., Guilderson, T.P., Hajdas, I., Heaton, T.J., Hogg, A.G., Hughen, K.A., Kaiser, K.F. Kromer, B., McCormac, F.G., Manning, S.W., Reimer, R.W., Richards, D.A., Southon, J.R., Talamo, S., Turney, C.S.M., van der Plicht, J., Weyhenmeyer, C.E., 2009. IntCal09 and Marine09 radiocarbon age calibration curves, 0-50,000 years cal BP. Radiocarbon 51 (4), 1111-1150.

Retana, J., Espelta, J.M., Habrouk, A., Ordoñez, J.L., de Solà-Morales, F., 2002. Regeneration patterns of three Mediterranean pines and forests changes after a large wildfire in northeastern Spain. Ecoscience 9, 89-97.

Rivas-Martínez, S., 1964. Relaciones entre los suelos y la vegetación en la comarca de la Puebla de Lillo (León). Anales Edafol. Agrobiol. 23 (5-6), 323-333.

Rodrigo, A., Retana, J., Picó, F.X., 2004. Direct regeneration is not the only response of Mediterranean forests to large fires. Ecology 85, 716-729.

Rodríguez Guitián, M.A., Ramil-Rego, P., 2008. Fitogeografía de Galicia: análisis histórico y nueva propuesta corológica. Recursos Rurais $1,19-50$.

Roig, S., Gómez Manzaneque, F., Masedo, F., Morla, C., Sánchez, L.J., 1997. Estudio paleobotánico de estróbilos y maderas subfósiles holocenas en el yacimiento de Cevico Navero (Palencia, España). Anales Jard. Bot. Mad. 55, 111-123.

Rubiales, J.M., García Amorena, I., García Álvarez, S., Gómez Manzaneque, F., 2008. The Late Holocene extinction of Pinus sylvestris in the west of the Cantabrian Range. J. Biogeogr. 35, 1840-1850.

Rubiales, J.M., Ezquerra, FJ. Gómez Manzaneque, F, García Álvarez, S. GarcíaAmorena, I., Morla, C., 2009. The long-term evolution of the Cantabrian landscapes and its possible role in the cappercaillie drama. Grouse News 38, 9-11.

Rubiales, J.M., García-Amorena, I., Hernández, L., Génova, M., Martínez, F., Gómez Manzaneque, F., Morla, C., 2010. Late Quaternary dynamics of pinewoods in the Iberian mountains. Rev. Palaeobot. Palynol. 162, 476-491.

Rubiales, J.M., Hernandez, L., Romero, F., Sanz, C., 2011. The use of forest resources in central Iberia during the Late Iron Age. Insights from the wood charcoal analysis of Pintia, a Vaccaean oppidum. J. Archaeol. Sci. 38, 1-10.
Rubiales, J.M., Morales-Molino, C., García Âlvarez, S., García-Antón, M., in press. Negative responses of highland pines to anthropogenic activities in inland Spain: a palaeoecological perspective. Veg. Hist. Archaeobot. doi:10.1007 s00334-011-0330-2.

Ruhstaller, S., 1995. Materiales para la lexicología histórica. Estudio y repertorio alfabético de las formas léxicas toponímicas contenidas en el «Libro de la Monteria» de Alfonso XI. Max Niemeyer Verlag, Tübingen.

Salas, L., 1991. Análisis palinológico de la turbera de Pico Ano, implicaciones en las variaciones climáticas del Holoceno Final Actas de la VIII Reunión nacional sobre el Cuaternario, Valencia.

Sânchez Hernando, L.J., Gómez Manzaneque, F., Masedo, F., Morla, C., del Nido, J. 1999. Identificación de macrorrestos vegetales holocenos en las cuencas altas de los ríos Porma, Curueño y Esla (León, España). Bol. Real Soc. Esp. Hist. Nat (Secc. Biol.) 95, 31-42.

Santos, L, 2004. Late Holocene forest history and deforestation dynamics in the Queixa Sierra, Galicia, Northwest Iberian Peninsula. Mount. Res. Develop. 24, 251-257.

Schweingruber, F., 1990. Anatomy of European Woods, WSL/FNP. Paul Haupt Berne \& Stuttgart Publishers, Stuttgart.

Schweingruber, F.H., 2007. Wood structure and environment. Springer-Verlag, Berlin Heidelberg, New York, NY, USA, 280 pp.

Sevilla, F., 2008. Una teoría ecológica para los montes ibéricos. - IRMA-Junta de Castilla y León.

Stevenson, A., 2000. The Holocene forest history of the Montes Universales, Teruel, Spain. Holocene 10, 603-610.

Storch, I., 2007. Conservation status of grouse worldwide: an update. Wild. Biol. 13 5-12.

Stuiver, M., Reimer, P.J., 1993. Extended 14C database and revised CALIB radiocarbon calibration program. Radiocarbon $35,215-230$. CALIB 5.0 radiocarbon calibration program is available online on. http://radiocarbon.pa.qub.ac.uk/calib/.

Takhtajan, A., 1986. Floristic Regions of the World. California University Press, Berkeley, CA.

Théry-Parisot, I., Chabal, L., Chrzavzez, J., 2010. Anthracology and taphonomy, from wood gathering to charcoal analysis. A review of the taphonomic processes modifying charcoal assemblages, in archaeological contexts. Palaeogeogr Palaeoclim. Palaeoecol. 291, 142-153.

Trabaud, L., Campant, C., 1991. Problem of naturally colonizing the Salzmann Pine Pinus nigra Arn. ssp. salzmannii (Dunal) Franco after a fire. Biol. Cons. 58, 329-343.

Turner, C., Hannon, G.E., 1988. Vegetational evidence for Late Quaternary climatic changes in southwest Europe in relation to the influence of the North Atlantic Ocean. Philos. Trans. Roy. Soc. B 318, 451-485.

Urquijo, A., 1989. Altos vuelos. Precursores insólitos del turismo cinegético en la España del XIX. Aldaba Ediciones, Madrid.

Valbuena-Carabaña, M., López De Heredia, U., Fuentes-Utrilla, P., GonzálezDoncel, I., Gil, L., 2010. Historical and recent changes in the Spanish forests: a socio-economic process. Rev. Palaeobot. Palynol. 162, 492-506.

Valcarce, M.A., 1986. El dominio de la Real Colegiata de San Isidoro de León hasta 1189. CECEL, León.

Valdiosera, C.E., Garcia-Garitagoitia, J.L., Garcia, N., Doadrio, I., Thomas, M.G., Hänni, C., Arsuaga, J.L., Barnes, I., Hofreiter, M., Orlando, L., Götherström, A. 2008. Surprising migration and population size dynamics in ancient lberian brown bears (Ursus arctos). Proc. Natl. Acad. Sci. U S A 105, 5123-5128.

Vernet, J.L., Ogererau, P., Figueireal, I., Machado Yanes, C., Uzquiano, P., 2001. Guide d'identification des charbons de bois préhistoriques et récents: Sud-ouest de l'Europe: France, Peninsule Ibérique et Îles Canaries. CNRS.

Vincon, G., Pardo, I., 2004. The Stoneflies (Plecoptera) of the north west of the Iberian Peninsula. Ann. Limnolog. 40, 43-62.

Watts, W.A., 1986. Stages of climatic change from full glacial to Holocene in northwest Spain, southern France and Italy: a comparison of the Atlantic Coast and the Mediterranean Basin. In: Lowe, J.J., Gray, J.M., Robinson, J.E. (Eds.), Studies in the Lateglacial of Northwest Europe. Pergamon Press, pp. 101-111. 